\title{
The "Intrinsic Value" of Cultural Heritage as Driver for Circular Human-Centered Adaptive Reuse
}

\author{
Luigi Fusco Girard $^{1, *}$ and Marilena Vecco ${ }^{2}$ \\ 1 Interdepartmental Research Center in Urban Planning "Alberto Calza Bini", University of Naples Federico II, \\ 80138 Napoli, Italy \\ 2 Department of Accounting, Finance and Law, CEREN, EA 7477, Burgundy School of Business, \\ Université Bourgogne Franche-Comté, 21000 Dijon, France; marilena.vecco@bsb-education.com \\ * Correspondence: girard@unina.it
}

check for updates

Citation: Fusco Girard, L.; Vecco, M. The "Intrinsic Value" of Cultural Heritage as Driver for Circular Human-Centered Adaptive Reuse. Sustainability 2021, 13, 3231. https:// doi.org/10.3390/su13063231

Academic Editors: Marc A. Rosen and John Carman

Received: 14 January 2021

Accepted: 7 March 2021

Published: 15 March 2021

Publisher's Note: MDPI stays neutral with regard to jurisdictional claims in published maps and institutional affiliations.

Copyright: (C) 2021 by the authors. Licensee MDPI, Basel, Switzerland. This article is an open access article distributed under the terms and conditions of the Creative Commons Attribution (CC BY) license (https:/ / creativecommons.org/licenses/by/ $4.0 /)$.

\begin{abstract}
By referring to the European Green Deal, this paper analyzes the "intrinsic value" of cultural heritage by investigating the human-centered adaptive reuse of this heritage. This implies questions such as how to improve the effectiveness of reuse, restoration, and valorization interventions on cultural heritage/landscapes and how to transform a cultural asset into a place, interpreted as a living ecosystem, to be managed as a living organism. The autopoietic characteristic of the ecobio-systems, specifically focusing on the intrinsic versus instrumental values of cultural heritage ecosystem is discussed in detail. Specifically, the notion of complex social value is introduced to express the above integration. In ecology, the notion of intrinsic value (or "primary value") relates to the recognition of a value that "pre-exists" any exploitation by human beings. The effectiveness of transforming a heritage asset into a living ecosystem is seen to follow from an integration of these two values. In this context, the paper provides an overview of the different applications of the business model concept in the circular economy, for a better investment decision-making and management in heritage adaptive reuse. Matera case is presented as an example of a cultural heritage ecosystem. To conclude, recommendations toward an integrated approach in managing the adaptive reuse of heritage ecosystem as a living organism are proposed.
\end{abstract}

Keywords: cultural heritage; circular economy; intrinsic value; circular business model; business model; ecosystem; European Green Deal

\section{Introduction}

The functional reuse [1] cultural heritage is proposed here as the entry point to the implementation of a circular economy (CE). Such reuse is no longer interpreted as only "green", as proposed in the European Green Deal [2], but also firmly integrated within a cultural, social, and human paradigm.

This is a basic requirement to better take into account all of the values involved when managing cultural heritage. An integrated approach can capture the ecological perspective, more traditional values (e.g., economic), and a systemic perspective. Furthermore, the "philosophy" to restore and maintain cultural heritage without (re-)using it is no longer sustainable $[3,4]$ : it leads to a waste of resources.

The "ideal" project [5] of re-use and thus the main goal of regeneration is to transform a dead site (decayed because without possible use) into a living system, to be managed as a living organism, i.e., an organism capable of continuous adaptation to a changing/dynamic context through learning, re-organizing, repairing, and self-regulating in coherence with its "memory", and therefore capable of being resilient [6].

This paper discusses the ways in which adaptive reuse in a CE can be implemented, starting by discussing some fundamental problems with existing approaches taken to heritage assets reuse. In most approaches, attention is paid to the asset's attractiveness and its multidimensional impacts [7], and the economic, environmental, social, and cultural 
dimensions are interpreted as having the same weight. In this paper, by focusing on the ecological dimension, we centralize the health of nature and thus human beings' health, well-being, and happiness. The aim is to underline the "comprehensive" productivity of adaptive reuse at the micro and meso scale as a human, cultural, and social-shaped vision that can support the green and digital transition.

The need to consider and value the ecological system as well as natural capital, both of which are assumed to be central for human welfare, is not new in economics [8]. However, it is not yet common practice in business to take into account the free natural capital as the source of natural ecosystem services that sustain economic activities. A holistic approach is required to develop the vision of a sustainable future. Clearly, environmental actions should be implemented in the economic and social sphere as well. Jackson [9] affirms that a sustainable economy should be characterized by:

- A system that encourages minimizing consumption, or imposes personal and institutional caps or quotas on energy goods, water, etc.;

- A system designed to maximize societal and environmental benefits, rather than prioritizing economic growth;

- A closed-loop system where nothing is allowed to be wasted or discarded into the environment; which reuses, repairs, and re-makes before recycling;

- A system that emphasizes delivery of functionality and experience, rather than product ownership;

- A system designed to provide fulfilling, rewarding work experiences for all that enhances human creativity and skills.

- A system built on collaboration and sharing rather than on aggressive competition.

A sustainable economy should be characterized by sustainable development. The objective is to satisfy current needs without harming the ability of future generations to satisfy their needs [10], considering the limitations of earth's resources in the face of human development [11,12]. Synergies and trade-offs must be made between economic, environmental, and social goals [13].

In the quest to achieve sustainable development, the concept of $\mathrm{CE}$ becomes central and is increasingly assumed as a complete or partial solution to these challenges [14]. The concept of CE dates back to the 1990s. According to Andersen [15] and Su et al. [16], it had been introduced by David Pearce in 1990. This concept holistically considers the relationships between the four economic functions of the environment: as an amenity value, its function as a resource base, as a source of economic activities, and its role as a lifesupport system. However, as Geissdoerfer et al. [17] recall, another scholar, Stahel [18], had introduced the concept earlier. Stahel outlined a self-replenishing system that minimizes material, energy input, and environmental deterioration, avoiding the creation of negative externalities that can impact society's growth and progress. Within both concepts of CE the need to shift from linear to circular business models [19] can be found, with sustainability relying on the creation of an economy grounded on the reuse, recycling, and regeneration of materials.

This paper proceeds as follows. Section 2 discusses the European Green Deal strategy of EU, while Section 3 introduces the need to move to a new form of management within this transitional policy framework. Section 4 outlines the autopoietic characteristic of eco-bio-systems, specifically focusing on the intrinsic versus instrumental values of cultural heritage ecosystems. Section 5 provides an overview of the different applications of the business model concept under the circular economy perspective while also considering intangible intrinsic values, to inspire better investment and management decision-making in heritage reuse. Finally, Section 6 presents Matera as an example of a cultural heritage ecosystem. The paper concludes by providing some recommendations toward an integrated approach in managing the adaptive reuse of heritage ecosystem as a living organism, by combining instrumental and intrinsic values. 


\section{The European Green Deal Strategy}

The European Green Deal strategy of the European Union [2] is assumed. We reinterpret and re-shape it in the social and cultural dimension, stressing the role of the two key components for human-centered development. First, cooperative capacity, able to stimulate synergies and symbioses through circular relationships, and the integration capacity, which transforms cultural assets into ecosystems of economic, social, and cultural values. Second, financial sustainability, as these ecosystems should become self-sustaining ecosystems-characterized by a circular organization/structures-able to sustain themselves, without or reducing external support from public, private, or third sector institutions [20].

Our interpretation of functional or adaptive reuse moves towards the transformation of a site "lacking vitality/life" and devoid of use into a living organism. Considering the centrality that the ecological dimension today assumes or should assume, as demonstrated by the pandemic crisis, adaptive reuse must become a producer of primarily ecological or environmental values. The site must be transformed into an ecosystem that can also contribute to the vitality of the local context, involving other subjects and activities especially in its management, and possibly generating other ecosystems.

New activities in the reuse of cultural assets produce goods and services for external bodies, but they also re-produce their own production processes, regenerating themselves through the production of new knowledge and innovations. An adaptive management approach is required, able to continuously react to internal and external forces, learning from experiences and thus becoming resilient.

This cultural asset ecosystem should be able to capture the energy it requires from sun, wind, and geothermal sources and to implement a new metabolism that mimics that of nature. Cooperation and competition strategies are integrated in this model [21], which can regenerate itself from the bottom up. More and more, digital technologies facilitate the above behaviors. This is in contrast to the traditional recovery strategy of cultural heritage, which is generally indifferent to green needs. For example, the direct/indirect employment capacity in the redevelopment phase is often emphasized in comparison to other investments.

But the organization as well as the management of a reused cultural asset is a critical issue. It should be interpreted in a way similar to the nature of an organizational structure. The example of trees is very clear: they rely on energy from the sun and are characterized by a perfect metabolism. Thus, the analogy with trees allows us to imagine a functional reuse that contributes as much as possible to lowering pollutant and climatechanging concentrations, purifying the air, generating oxygen, reducing carbon dioxide, dust, noise, combustion residues, mitigating heat islands and thus helping to improve the local microclimate as well as providing fibers, fruits and wood, and managing water with care $[6,20]$.

This interpretation of the functional reuse of cultural heritage in the perspective of CE is framed by the lens of bio-ecology [22]. Functional reuse then becomes an opportunity for the realization of a living system, characterized by a specific metabolism that imitates that of nature as much as possible. Adaptive reuse is placed in a systemic perspective that connects in a mutual relationship the built and natural environment and manufactured and natural capital with human and social capital. This means that attention is paid to a coherent landscape integration, the permeability of the land, the capacity to use natural lighting, and to increase the environmental performance of the physical asset [6].

Reuse, especially in its management phase, can be defined as the promotion of a complex, dynamic, and adaptive system. This must be continuously rebuilt with an innovative management effort, taking into account the high density of interdependencies between the economic, social, and ecological subsystems and the positive sum strategies that can be triggered.

Such management is achieved through choices that are particularly complex because they require the recognition of the multiple dimensions in which the value of cultural 
heritage is expressed. It possesses values of use and values that are independent of direct use. But it also possesses "intrinsic anthropocentric and non-anthropocentric values" that complement (and counterbalance) the former. It is necessary to recognize each of these in the choices related to reuse.

The above implies interdisciplinary/trans-disciplinary models for decision-making, with an approach that can include many kinds of knowledge, from social to economical to ecological etc., in its evaluation. On the other hand, the reference to the ecological foundation of the economy and to human-centered strategy leads to changes in current evaluation practices, with the resulting need to identify new evaluation approaches, criteria, and indicators.

The "reintegration" of the economy into ecology [21] as well as the centrality of the ecological dimension that characterizes the European Green Deal [2] is wholly coherent with the World Health Organization Manifesto for facing the post-Covid19 challenge [23,24]. It makes explicit the impacts of climate change and pollution of the territory system primarily on health and thus on people's perception of well-being. Health is in fact a value with respect to which there is a general consensus (regardless of culture and geography).

\section{Toward a New Management}

The multiple activities in the adaptation of the heritage ecosystem have to be planned and managed over time as a living organism, i.e., following a circular organizational strategy. In other words, this means that the activities should be interdependent with each other and with the external context, in order to promote new and more efficient metabolisms and possibly generate other autopoietic, generative, or osmotic processes. For example, for productive activities, new entrepreneurs may add to pre-existing initiatives, therefore generating new business. Activities tend to reorganize themselves in new networks of interdependencies, in which the relationships of complementarity multiply with mutual convenience. Total productivity tends to increase, at least until the interdependencies begin to rarefy and dissolve over time. Then phenomena of decline emerge, which can nonetheless also be a source of new opportunities or activities, and therefore new value and employment. The processes of production, decay, and re-making, characterizing all living ecosystems, are visible here.

The different conditions for the effective functioning of a heritage ecosystem range from decentralized organization (in which each component self-organizes) to the metabolism that imitates natural ecosystems by avoiding any form of waste and enhancing all complementarities. They both include the ability to close resource loops and adaptive capacity over time with respect to changes in the context.

The CE model is interpreted here as a hybrid model between the economy of nature and the economy of humans: between economy and ecology. Furthermore, it is also a balance between competition and cooperation and between the market economy and social economy. Such symbioses are characteristic of the $\mathrm{CE}$, as the interactive and mutual relationships between different organizations that in specific crisis times survive or become more productive by using assets and resources more efficiently. Real life is rich with symbiotic processes, with dynamic and changing relationships between receiving and doing and different levels of efficiency in the metabolism.

In nature, every living organism not only consumes resources and energy but in turn, being related to other living organisms, nourishes and provides a flow of services to others. Natural ecosystems are characterized by an effective metabolism, perfectly developed over millennia, that imply the recycling of every by-product, the avoidance of waste, and the sustaining of new vital processes. Essentially, the CE is the economy that mimics the nature economy in its circular processes. It is thus a re-generative economy and for this reason able to become generative of multiple impacts, specifically:

- $\quad$ It is the economy grounded on ecology and ecological values: on primary/glue values;

- It implies an approach to sustainability as self-sustainability. In CE the notion of value is a complex and systemic one: economic, social, and ecological values are 
intertwined. In this perspective, instrumental values are also considered in relation to the intrinsic values. Thus, the CE model enriches the notion of value in the perspective of a complex economic, ecological, and social value (Complex Value) $[4,25,26]$;

- It is attentive to avoid the under use and waste of all kinds of capital, including natural and man-made capital but also human and social capital. These last forms of capital are very important. For example, if we apply this perspective to the city, the city is often not only characterized by a great quarry of waste or discarded elements, but also by the quarry of discarded people: unemployed, marginal, or poor people, etc. The CE should be focused to avoid this under use or waste of the human capital, that is to say, of a human being's capacity for intelligence, knowledge, abilities, creativity, and self-entrepreneurship.

The concept of complementarity becomes essential in the CE. It expresses the relationship of mutual benefits between different components: the presence of one element leads to an increase in value to the benefit of other components due to specific interdependencies. It is not enough to reduce, repair, recycle, or to use natural resources to become more productive for the implementation of the $\mathrm{CE}$. The essential aspect of the $\mathrm{CE}$ is the successful search for systemic complementarities between different functions, activities, and subjects on the basis of reciprocal exchanges of by-products that become productive inputs for other activities. Thus, in the CE approach, single elements should be transformed into "components of a system" [20].

\section{The Autopoietic Characteristic of the Eco-Bio-Systems: Intrinsic Versus Instrumental Values}

\subsection{A Complex Notion of Value}

In ecological economics $[8,27,28]$, a complex notion of value has emerged of economic, social, and environmental values. It combines value in itself (which is value independent from use) with instrumental values. Specifically, in the CE context, the introduction of the notion of "intrinsic value" is part of implementation of the CE model. The "intrinsic" value does not change with the objective, quantitative, or numerical assessment of a resource. It is not concerned with subjective or perceptive assessments in opposition to objective evaluations. In this perspective, subjective is linked to ordinal assessment by people and objective is linked to expert knowledge, to the numerical assessment of experts. The notion of intrinsic value is linked to bio-eco systems behaviors, to their self-regenerative capacity, and thus to their capacity to sustain the life of other subjects.

A bio-ecological system has a value in itself, which reflects its auto-poietic, selfproduction, and self-organization capacity [28-31]. In nature, there are different and wellknown processes of self-organization or regulation: the self-regulation of air composition, of solar energy photosynthesis, of biomass re-production, etc. They have an intrinsic value.

An autopoietic (self-organizing) system also has another role: to provide services and goods for supporting the life (in its various forms) of other subjects [32]. This heteropoietic aspect is linked to the use values recognized by human beings. Therefore, the autopoietic capacities of an eco-bio system highlight its ecological value, that is, its intrinsic value or its non-use/independence from any use. Heteropoietic capacities are linked to many possible use values and first of all to economic-generated values.

\subsection{Intrinsic Value}

The intrinsic, non-monetary, and non-instrumental values of nature are due to the fact that they guarantee, by autopoietic processes and effective metabolism, a slowdown in energy dispersion (a reduction of entropic degradation processes), clean air and water, temperature regulation etc., and thus the maintenance of all living species in their respective ecological "niches" [33]. This intrinsic value reflects the essential structure and capacity of a system to structure other components and/or sub-systems by reducing entropy and increasing order. In other words, the intrinsic value of a living system expresses a re- 
generative systemic capacity, which is a condition of generative capacity (of external effects etc.,) and also of symbiosis and resilience.

Turner [34] stressed the need to recognize a "primary value" in the autopoietic natural system (and therefore to the biotic and abiotic components linked by interdependent relationships) in terms of "glue" capacity: the capacity to unite different elements and components in a set of dynamic and reciprocal interdependencies.

This "primary value" is conditional for the system to provide useful functions and services to others. It is the value of the latent functions that underlie those generally observed and that express the value of the entire system: the flow of services to others [35]. This intrinsic value is the basis of use values and market values. Intrinsic values can exist without instrumental values. However, if the intrinsic value dissolves, economic values can collapse [34]. The autopoietic approach therefore gives rise to a notion of value that is intrinsically "complex": it is a combined ecological, social, and economic value.

The notion of "intrinsic value" has been proposed by Ruskin for artistic, cultural, and monumental heritage [36]. Riegl later proposed a notion of "essential meaning" [37]. Historically, the intrinsic value of cultural heritage can be traced back to the sense or meaning that different cultures have recognized in certain sacred or religious sites. For example, in the Hindu religion intrinsic value is associated with a spirit of places that "lives" in nature and that represents the foundation of its intrinsic value [38], making a specific place unique [39].

Heritage assets have often been an order structure for city development in that they have been able to orient a city's growth toward a specific direction [40]. But this intrinsic value differs from that of natural ecosystems because it has been produced, created, or recognized by people over a very long history and in the memory of a local system.

In a certain sense we can speak of "subjective" intrinsic value [41,42] as opposed to "objective", because it is a value recognized or created by certain subjects through their capacity for critical discernment. Intrinsic value does not exist per se, that is, independently of the subjects who have recognized it and recognize it as such. This subjective intrinsic value does not require a bio-centric or eco-centric vision. It remains anchored to the anthropocentric approach. Intrinsic value is compatible with a relational, i.e., interpersonal, community or collective approach. It is recognized from generation to generation.

Unlike instrumental value, intrinsic value is not replaceable or compensable [41]. From the irreproducibility that is connected to the non-substitutability, authenticity, integrity, and exceptionality of an artistic and heritage or object [4] derives a specific value assimilable to a value independent from use. This is a value that each generation, present as well future, can recognize as timeless or eternal. Certainly, values are socially constructed. They are dynamic in time as well as in space. But for cultural heritage, a value can be identified that tends, within certain limits, to be recognized over the long-term and from one generation to another.

The principle of intragenerational equity has been discussed in terms of the influence of public policy [43], economic valuation of heritage [44], and sustainability [45]. Throsby [44] defines it as follows: "The intragenerational equity dilemma is a classic intertemporal allocation problem - that is, a choice between present and future consumption". Both present and future consumption entails costs with respect to preservation and maintenance, but is it possible to define the first- or second-best option within this scenario? The point is to decide how far the principle of intragenerational equity and its authority should be applied, and what the impact is on the present generation. As Taylor [46] points out, the problem that arises in any intragenerational consideration is whether an action or resource will be valued in the future. Is it possible to understand the needs of future generations that are not concurrent with our own? Should we accept that intergenerational equity should be limited by the intragenerational one?

Future generations have the right to dispose of this cultural capital, even if at the present time it is absolutely devoid of any demand for use and the use value is nil. It is this "essential" value, independent from any use, that characterizes and differentiates 
this cultural manmade capital from other manmade assets capable of generating a similar activity (economic or financial flows, like a supermarket, etc.). This value goes above and beyond all other extractive and non-extractive values. This is another way to recognize a value that can be interpreted as an "intrinsic value" [40]

\subsection{Autopoietic Capacity and "Intrinsic Value"}

The "intrinsic value" can also be understood as being more directly linked to the autopoietic approach. The vitality of cultural heritage is represented by the way in which its presence and use influences the stability of the context and its resilience. It interacts with the living components of the socio-economic urban ecosystem, that is, with the past, present, and future community.

Intrinsic value is the essential significance or capacity of an asset, space, or site that was (and should be) able to remain permanently in the urban system in the context of continuous dynamic changes from one generation to another one. Yet it also has the energy to give a direction to the city or the site development, as a "telos" of the urban living systems [28].

Just as every organism has its own telos [28] - a fundamental purpose characterizing it and orienting its direction-so too have components of urban cultural heritage presented a direction of development throughout history. This capacity represents another linked aspect of the intrinsic value of cultural heritage. The vitality of heritage assets depends on their ability to adapt themselves to often-tumultuous change and to external pressures and shocks while maintaining the permanence of the elements that characterize its specificity and identity. In maintaining memory, cultural assets have the capacity to create and to become elements of social stability.

As "intrinsic value" reflects the specific, unique, irreproducible character and meanings, significance, identity, and beauty of a place, so too does it determine a sense of "connection" between different subjects and between community and manmade capital. There is a "circular" relationship or value among them.

Cultural heritage is the element by which a community can recognize itself today and in the future [47]. It is a source of local identity, integration, cohesion, community awareness, shared common values, and a specificity toward a homologating culture conveyed by mass-media technologies. Cultural heritage "tells us" where we come from; it gives us a homeland without which we would be lost, stateless persons; it helps us to recognize our roots and our identity. Cultural heritage is a relational element of reference, an "anchor" in a period of rapid transformation, in which the identity of a community, its memory, and its genetic heritage are expressed. At the same time, it represents an instrument with which each generation communicates with the next.

This intrinsic value is interpreted as the essential significance or meaning of cultural heritage, as it is the reflection of the way a community lives, works, and organizes itself though its knowledge, culture, and wisdom, thus becoming able to conserve itself in a continuous regenerative process. At the same time, it generates other use values according to the changing context.

Therefore, it seems possible to transfer the notion of intrinsic value from the heritage ecosystem to cultural heritage as a place. Indeed, intrinsic value is reflected in the "spirit of places" [48]: it is connected to the permanence of tangible and intangible elements over a long timeframe and to cooperative behaviors.

The set of anthropocentric instrumental and intrinsic values represents the overall systemic value of a cultural site or an historic urban landscape. Consequently, its intrinsic value becomes a further tool and argument for its preservation. In economic development plans, urban planning projects, and urban/territorial regeneration and management strategies, intrinsic value becomes something inherent to place, to their "statute", and to their landscape, and as such it deserves respect, care, attention, and enhancement. Overall, by recognizing both an instrumental and an intrinsic value to certain assets or resources, 
and if it is historically, culturally, or aesthetically based, we can better justify heritage conservation and care than with only an economic or instrumental approach.

As previously mentioned, the intrinsic value conferred to cultural heritage comes from a long-term evolutionary process, similar to that of ecosystems. What has been preserved is considered permanent in the continuous dynamics of the development of a city or territory because its people have recognized its value over time. It is the hidden organizational order, its memory, which is able to connect together different components, as in a natural ecosystem. The order structure "does not pass" in time and it is able to orient the area or site in a specific direction. However, intrinsic value differs from that of natural ecosystems because it has been produced/created/recognized by people over a very long history.

This is the reason why we can speak of "subjective" intrinsic value [41,42] and not objective: we can say that it is the result of an inter-subjective process. This subjective or inter-subjective intrinsic value (not requiring a bio-centric or eco-centric vision or approach) remains anchored to the anthropocentric and relational approach and renders useless the dichotomy between anthropocentric values and eco-bio-centric values. Therefore, this dichotomy can be eliminated [49].

\section{From Business Models to Circular Business Models}

In this section we analyze the business model (BM) concept and its evolution, with the goal of showing how the BM literature seeks to include and achieve sustainability and adapt to the CE. Influenced by different models, the authors present a circular BM (CBM) to synthesize the existing literature and provide a tool to analyze the adaptive re-use of the cultural heritage ecosystem.

The concept of a BM as a "theory of a business" is not new [50]. However, BM research only recently attained the attention of scholars. As a result, there is no commonly accepted definition: "[scholars] do not [readily] agree on what a business model is" [51]. The BM concept became popular in the 1990s with the emergence of e-commerce [51,52]. In this context, it was initially used to pitch simplified but comprehensive business ideas to investors within a short timeframe [53]. Furthermore, the BM concept has been used in different disciplines and contexts (e.g., e-business, innovation, strategic management, and entrepreneurship) with different perspectives. Unsurprisingly, the BM literature is still heterogeneous and fragmented [54].

In a review of different BMs, Zott et al. [51] identify four common themes. First, the $\mathrm{BM}$ is a new unit of analysis that bridges traditional ones, such as firm, industry, or network. Second, it emphasizes a system-level perspective involving simultaneous consideration of the content and process of "doing business". Third, it emphasizes the activities performed by the focal firm and its customer, partners, and suppliers. Finally, it explains value creation and value capturing. A BM can be viewed as a social construct [55]. As Nielsen [56] claims, "the BM concept is perhaps the most discussed and at the same time the least understood of the newer business concepts" [56]. Based on these comparative approaches, we can assume that a business model is a simplified representation of the elements of a complex organizational system and the inter-relation between these elements.

BM definitions vary in their nature and level of detail. Some are very detailed (e.g., Al-Debei and Avison [57]) while others are more abstract (e.g., Eriksson and Penker [58]). The oldest BM definition was proposed by Timmers, who defined a BM as "an architecture for the product, service, and information flows, including a description of the various business actors and their roles; and a description of the potential benefits for the various business" [59]. The business model may be viewed as a new unit of analysis in business, which considers these collaborative ties existing in the ecosystem of the business of reference $[51,60]$. This idea of considering BMs as a bridge connecting different actors that compose the business ecosystem is followed by other authors like DubossonTorbay et al. [61], Mahadevan [62], and Shafer et al. [63]. Other key elements of BM definitions relate to value creation, delivery, and capture (e.g., Teece [64]). 
Biloslavo et al. [65] classified the 20 existing BM definitions into six types: organizational design [57-59,61,66-69], resource-based [63,70-72], narrative and sense-making [73,74], transactive structures [62,75], nature of innovation [76], and opportunity-driven [52,64,77].

Three distinct conceptual perspectives on BMs exist: the elements-based perspective, the activity system perspective, and the value-based perspective. The elements-based perspective assumes that a BM is a configuration of distinct elements [78,79]. This research stream offers practical tools for BM design, such as the business model canvas [52] as well as instruments for measuring BM and the extent of BM innovation [80,81]. The activity system perspective considers that a BM is a system of inter-related and interdependent activities that allows a firm to create value and competitive advantage [73,82]. It describes the BM as the way activities and resources are used to conduct business and achieve growth [79]. Finally, the value-based view defines the BM as a "representation of how a business creates and delivers value, both for the customer and the company" [83], or as "the way organizations or individuals communicate, create, deliver, and capture value out of a value proposition" [84]. The value-based view typically involves value dimensions and their constituent elements. In general, at least three core value dimensions are included: (1) customer value proposition; (2) value creation, value architecture, or business infrastructure; and (3) value capture or profit generation. In this perspective, BMs provide a holistic and systemic understanding of how activities for value creation are orchestrated [85].

According to Schaltegger et al. [86], the BM approach is particularly interesting in the context of sustainability because it underlines the value creation logic of an organization and its effects. It can lead to the development of new governance forms such as cooperatives, public private partnerships, or social businesses that can transcend narrow for-profit and profit-maximizing models. This is particularly relevant as it is clear that no sustainable value can be created for customers without creating value for a broader range of stakeholders.

For the purpose of this article, a BM is understood as "the rationale of how an organization creates, delivers and captures value" [52], while a sustainable BM is one that combines the CE's challenges and the practice-oriented approach of BM innovation in how it incorporate elements that slow, narrow, and solve resource loops. This is the perspective needed to decrease resource input into the organization and its value network by minimizing waste and emission leakage out of the system [87]. According to Geissdoerfer et al. [17], "the biggest difference between conventional business models and those designed for CE lies in their value creation and delivery element, and here particularly in the supply chain" [17].

In the recent years, the literature on the theory of BM for delivering sustainability has grown. As recalled by Rosa et al. [88], the extant literature already proposed and classified these as sustainable BMs. CBMs can be divided into six "archetypes" according to the ReSOLVE framework [89]:

(1) Regenerate. Actions focused on: (i) shifting to renewable energy and the production of secondary materials, (ii) reclaiming/retaining/restoring the health of the ecosystem, or (iii) returning recovered biological resources to the biosphere;

(2) Share. Actions focused on: (i) sharing assets, (ii) reuse/second hand, or (iii) prolonging product lifetime through maintenance;

(3) Optimize. Actions focused on: (i) increasing performance/efficiency of products, (ii) removing waste in production and supply chains, or (iii) leveraging big data, automation, remote sensing, and steering;

(4) Loop. Actions focused on: (i) remanufacturing of products/components, (ii) recycling of materials, (iii) anaerobic digestion of wastes, or (iv) extraction of biochemicals from organic waste;

(5) Virtualize. Actions focused on direct or indirect dematerialization of products;

(6) Exchange. Actions focused on: (i) replacing old materials with advanced nonrenewable ones, (ii) applying new technologies in traditional processes or (iii) transforming products/services. 
Many scholars use the ReSOLVE framework for developing their own specific classification methods even though it cannot be considered as an acknowledged classification method. For example, Charter [90] tried to put in practice the theoretical framework of ReSOLVE by categorizing CBMs into two macro classes and six sub-segments. Manninen et al. [91] exploited the ReSOLVE framework to develop an Environmental Value Proposition Table (EVPT) to include the environmental dimension in the value proposition of CBMs. Finally, Mendoza et al. [92] added the "Implement" level to the original ReSOLVE framework to cover the gap between theoretical principles and their practical implementation.

BMs for sustainability are "characterized by creating economic success through a certain ecological or social activity" [93]. A sustainable BM that tries to combine multiple institutional logics is a prototype example of a paradox tension, which refers to the existence of "contradictory, yet inter-related elements that exist simultaneously and persist over time" [94]. Sustainable BMs incorporate sustainability as an integral part of the company's value proposition and value creation logic. As such, they provide value to the customer and to the natural environment and/or society.

Stubbs and Cocklin [95] assume that BMs that want to be sustainable use both a system and firm-level perspective and build on the triple bottom line approach to define the firm's purpose and measure performance, include a variety of stakeholders, and explicitly assume the environment as well as society as key stakeholders. Therefore, the key challenge is how to design business models that enable a firm to capture economic value for itself while delivering social and environmental benefits and values [93]. Sustainable business models (SBMs) go beyond the firm's entity as their organizational boundaries are represented by society and by the environment, and focused on the capture of economic, social, and environmental value for a wide range of stakeholders [96]. Stubbs and Cocklin [95] suggest six different propositions to characterize SBMs:

- The organizational purpose has to be defined in terms of ecological, social, and economic outcomes. Therefore, financial profits are rather a means than an end and sustainability is "the right thing to do".

- The prioritization of the success of stakeholders as an organization's success is directly linked to the wellbeing of its various stakeholders.

- Nature has to be assumed as a stakeholder and negative effects on it should be minimized or eliminated.

- The value proposition should be holistically thought: the creation of value should go beyond mere customer value.

- Visionary leaders who motivate cultural and structural change and embed a "sustainability mindset" throughout the organization implement this business approach.

- Appropriate performance measurement and management systems and sustainability accounting and reporting have to be introduced to support this mindset.

Following Bocken et al. [96] and Geissdoerfer et al. [97], BMs for the CE have to be considered as a class of or generic strategy for SBMs: "By closing, narrowing, slowing, intensifying, and dematerializing loops, the resource inputs into and the waste and emission leakage out of the organizational system are minimized, and, consequently, the sustainability performance improved" [17].

SBMs are BMs with the objective of creating solutions for sustainable development by delivering additional monetary and non-monetary value. They do so by the proactive management of multiple stakeholders and by incorporating a long-term perspective. Specifically, SBMs incorporate principles or practices from the CE as guidelines for BM design. SBMs aim to boost resource efficiency and effectiveness and ultimately close energy and resource flows by changing the way economic value and the interpretation of products are approached $[87,98]$.

Figure 1 explores this correlation by contrasting circular and linear representations of the value proposition, value creation and delivery, and value capture element of a $\mathrm{BM}$ with its economic, environmental, and social performance. Each BM element (value 
proposition, creation and delivery system, and value capture) is affected by four core issues of corporate sustainability economic, environmental, and social dimensions, and a long-term orientation $[99,100]$. Naturally, all three elements of a business model (value proposition, value creation and delivery, and value capture) have to "go circular" to achieve optimal sustainability within the CE.

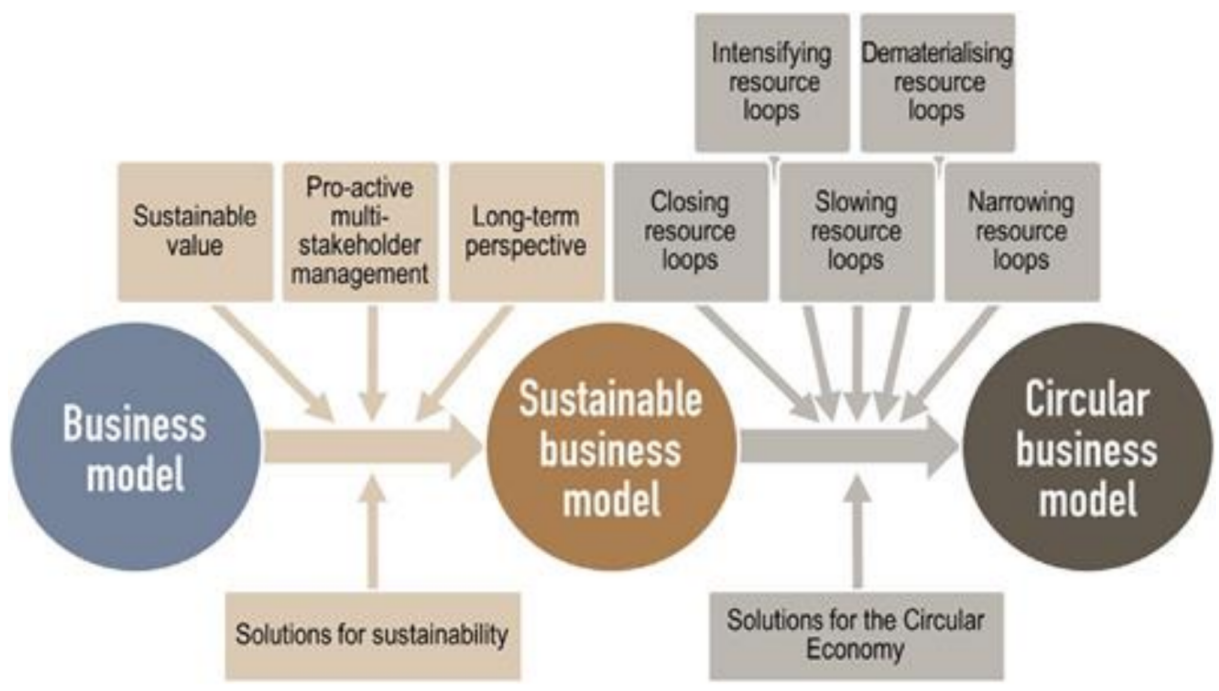

Figure 1. Comparison of traditional, sustainable, and circular business models (BMs). Source: Geissdoerfer et al. [17]

The incorporation of circular principles into BMs also occurs at different levels, depending on decision-makers' ambitions and adopted strategies. Urbinati's et al. [101] taxonomy suggests three available modes of integrating CE principles in BMs: downstream circular (altering value capture and delivery through new revenue schemes and customer interface, e.g., pay-per-use models), upstream circular (changing value creation systems, e.g., reverse logistics), or fully circular (combining upstream and downstream principles). Furthermore, CE-oriented BMs also add uncertainty and complexity to conventional BMs. New variables have to be considered, for instance, reverse on top of forward logistics; quality, quantity, and timing of the return of resources; and customers' perceptions and preferences for "as new" [102]. This requires a systemic and transdisciplinary view, which has been reflected in recent publications exploring the interfaces of CE-oriented BMs with other innovation perspectives, such as product design, value chain, and digital technologies $[17,87]$.

In their review, Geissdoerfer et al. [97] identify that existing definitions have in common that they see SBMs as a modification of the conventional BM concept, with some characteristics and goals added to it. Furthermore, "they either (1) incorporate concepts, principles, or goals that aim at sustainability; or (2) integrate sustainability into their value proposition, value creation and delivery activities, and/or value capture mechanisms" [17]. Their review describes different subcategories, archetypes, or generic strategies for sustainable business models, like product-service systems, base of the pyramid, or CBMs [96,103].

Boons and Lüdeke-Freund [104], based on a literature review, propose basic normative requirements for each of the constituting elements of BMs. The value proposition must provide both ecological or social and economic value through offering products and services; the business infrastructure must be rooted in principles of sustainable supply chain management; the customer interface must enable close relationships with customers and other stakeholders to be able to take responsibility for production and consumption systems (instead of simply "selling stuff"); and the financial model should distribute economic costs and benefits equitably among actors involved. According to these authors, a BM for sustainability helps describe, analyze, manage, and communicate (i) a company's 
sustainable value proposition to its customers and all other stakeholders, (ii) how it creates and delivers this value, and (iii) how it captures economic value while maintaining or regenerating natural, social, and economic capital beyond its organizational boundaries.

Franca et al. [105] note that traditional BM concepts poorly capture the particularities relating to the sustainability dimension: the need to consider a wide range of stakeholders, to capture social value creation, and to consider long-term social value capture. In response, the authors combine the principles of the "framework for strategic sustainable development" [106] with the BM Canvas [52] into the sustainable BM. Furthermore, several studies have emphasized the categorization of SBMs for sustainability into archetypes divided across ecological, social, and economic categories [103,107].

Finally, we can identify two types of sustainability with implications for the business model: weak and strong sustainability [108]. We learn that "Weak sustainability sets out to bring environmental concerns into the framework provided by the structures and systems of business. In contrast, strong sustainability seeks to integrate the company into environmental or socio-ecological systems" [108]. Weak sustainability induces incremental change, while strong sustainability is more radical and is based on system thinking combined with organizational and social innovation.

In the next paragraph, we review the most recent approaches on sustainable BM in the literature to show the main trends and patterns they adopt to meet the CE challenges.

There are many different types of SBMs [103,109]. Classifications may vary according to the criteria used. For example, the entity driving the business model, such as social enterprises [110], hybrid organizations [111], social enterprises [112], Product Service Systems [113,114], or the rationale characterizing the BM product service systems [113] and closed-loop [115,116] or circular models [91]. On the top of that, sustainable BMs in the literature include "Natural Capitalism" [117], new economy concepts (e.g., Blue Economy; [118]; Cradle to Cradle [119], Laws of Ecology [120], Looped and Performance Economy [121], Regenerative Design [122], Industrial Ecology [123], and Biomimicry [124].

Lewandowski's [125] study employs a literature review to identify and classify the CE characteristics according to a BM structure. The investigation in the eight sub-domains of research on CBMs allowed them to re-define the components of the business model canvas in the context of the CE. Overall, his BM structure comprises 11 components:

(1) Value propositions - offered by circular products enabling product-life extension, productservice system, virtualized services, and/or collaborative consumption. Moreover, this component comprises the incentives and benefits offered to customers for bringing back used products;

(2) Key resources - choosing suppliers offering better-performing materials, virtualization of materials, resources allowing the regeneration and restoration of natural capital, and/or resources obtained from customers or third parties meant to circulate in material loops (preferably closed);

(3) Key activities_-focused on increasing performance through good housekeeping, better process control, equipment modification and technology changes, sharing and virtualization, and on improving the design of the product to make it ready for material loops and more eco-friendly. Key activities can also include lobbying;

(4) Key partnerships — based on choosing and cooperating with partners along the value chain and supply chain;

(5) Customer segments - directly linked with value proposition. Value proposition design depicts the fit between value proposition and customer segments;

(6) Channels - possibly virtualized through selling virtualized value proposition and delivering it also virtually, selling non-virtualized value propositions via virtual channels, and communicating with customers virtually

(7) Customer relationships - underlying production on order and/or what customers decide, and social-marketing strategies and relationships with community partners

(8) Revenue streams - relying on value propositions and comprising payments for a circular product or service, or payments for delivered availability, usage, or performance 
related to the product-based service offered. Revenues may also pertain to the value of resources retrieved from material loops;

(9) Cost structure-reflecting financial changes made in other components of CBM, including the value of incentives for customers. Special evaluation criteria and accounting principles must be applied to this component;

(10) Take-Back system - the design of the take-back management system including channels and customer relations related to this system;

(11) Adoption factors - these show that the transition toward CBM models must be supported by various organizational capabilities and external factors.

Although this BM structure emphasizes the relevance of adopting factors, it does not overcome an industrial production perspective as the design of a take-back system is not fully appropriate and relevant in services (intangibles) delivery. Lewandowski's two new components (the take-back system and the adoption factors) allow the conceptualization of an extended framework for the CBM canvas.

According to Lüdeke-Freund and Dembek [126], an increasing number of scholars and practitioners go beyond value creation in economic or financial terms and explore the potential of BMs to solve ecological and social problems, and in particular, the challenge to move toward corporate sustainability $[86,103,126]$.

Several authors describe iconic cases of companies that aim to reduce the pressure on ecological and social systems through their business models (e.g., [95,104]) and that propose archetypal BMs for sustainability $[103,127]$. All these cases and BM types bear the potential to provide inspiration or even useful solutions for established companies and start-ups facing similar challenges. Upward and Jones [128], taking a "strongly sustainable" perspective, formulate four propositions to characterize BMs:

- A strongly sustainable BM creates ecological, social, and economic value and takes its embedding value network into account, which implies an extended understanding of the value that is proposed, delivered, and finally created.

- The concept of value itself is broadened to forms of value that meet the needs of actors in aesthetic, psychological, physiological, utilitarian, and/or monetary terms.

- This extended perspective on a BM's value network and understanding of value requires a systemic conception of business models as being embedded within wider ecological, societal, and economic contexts.

- A new kind of metric is created, "tri-profit". This integrates all forms of value creation into one single measure instead of measuring these in parallel, as with traditional triple bottom line approaches.

Joyce and Paquin [129] suggest the Triple Layered Business Model Canvas as a tool for exploring sustainability-oriented business model innovation. It is presented as "a practical tool for coherently integrating economic, environmental, and social concerns into a holistic view of an organization's business model" [129]. It extends the original business model canvas by adding two layers: an environmental layer based on a lifecycle perspective and a social layer based on a stakeholder perspective. When taken together, the three layers of the BM make more explicit how an organization generates multiple types of values-economic, environmental, and social. A holistic impact approach is proposed, linking economic impacts to social and environmental ones. It also creates two new dynamics for analysis: horizontal coherence and vertical coherence (Figure 2). This tool fits a decision-making approach, both in a business and in a policy-maker perspective. 


\section{Horizontal coherence}

\section{Vertical coherence}
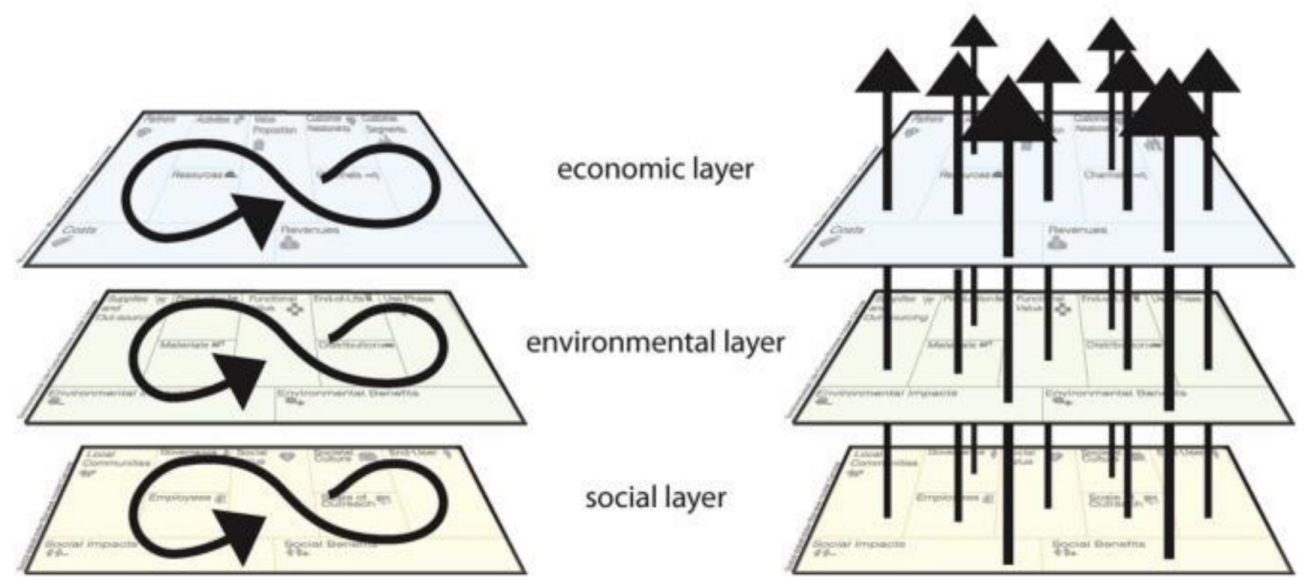

Figure 2. The double coherence of the triple layered business model canvas. Source: [129].

Joyce and Paquin's model provides "horizontal" coherence within each canvas layer for exploring economic, environmental, and social value individually and "vertical" coherence as it integrates value creation across the three canvas layers. According to Lozano [99], this is assumed as relevant as it supports developing a deeper understanding of an organization's value creation.

By reviewing the BM literature, Ritter and Lettl [130] identify the following perspectives: $\mathrm{BM}$ activities (in which a BM is viewed as a description of the activities that the firm has put together in order to execute its strategy), BM logics (which describe the flow of logical arguments summarizing the logic of the business), BM archetypes (which are typical models of value creation and value capture transcending industry boundaries), BM elements, and BM alignment. Each of these five perspectives has a distinct way of defining $\mathrm{BM}$ and all of them are meaningful in their own approach. These scholars suggest that the five perspectives can co-exist as they complement each other. However, they need to be explicitly applied and distinguished from each other in order to avoid ambiguity and confusion.

Dentchev et al. [131] note that the extension of the BM conceptualization to the field of SBMs remains in its early stages of development: the operationalization of sustainabilityrelated concepts remains challenging because the "value" inherent in SBMs is subject to debate going beyond value (creation) as expressed in economic terms only. Economic value remains easier to evaluate and measure, for instance through the examination of the company's financial and accounting reports, as compared to social or environmental value created by SBMs, which is much harder to objectively evaluate or express in financial therefore quantitative terms. Furthermore, these authors observe that the varying contextual settings do not only refer to cultural contexts, industrial sectors, or types of organizations (like for-profit and not-for-profit ones), but also to the level of analysis at which the SBMs are studied. The level of analysis can be situated at the individual, team, organizational, inter-organizational, regional, national, or multinational level. This brings the role of governments and various governance mechanisms, often important for encouraging the development of SBMs, to the fore. Without government regulation, there is a danger that social and environmental impact of SBMs will remain underdeveloped in many settings.

By analyzing the 20 most often cited BM frameworks, Biloslavo et al. [65] explore the conventional understanding of the business models and reflect on gaps in the current perspectives of sustainability. Their analysis shows that existing BM frameworks exclude both natural and social aspects of organizational environment from the discussion and tend to neglect the inter-relationships between economic and non-economic actors as well as the intertemporal trade-offs. To fill in this gap, these scholars introduce a new sustainable 
business model framework named the "Value Triangle" (VT), which explicitly includes society's incorporation of the natural environment, future generations, and three types of co-created and co-delivered value: public, partner, and customer (Figure 3).

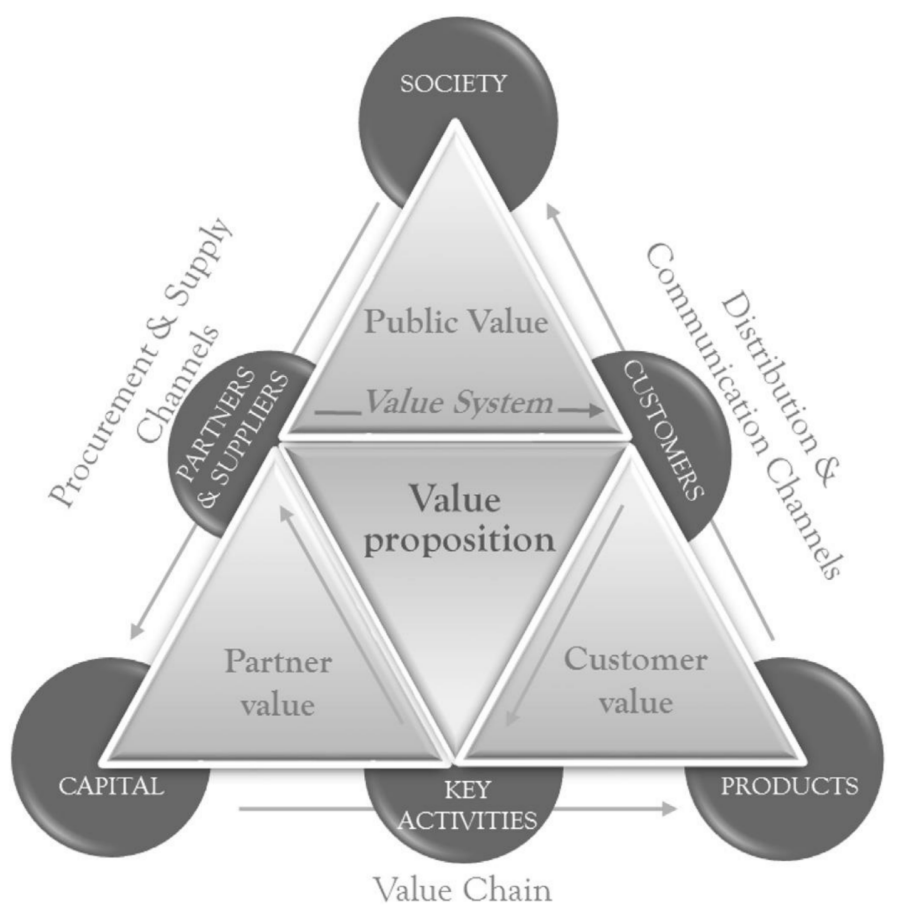

Figure 3. The value triangle. Source: [65].

Aligning with these views, Pieroni et al. [132] provide a review of approaches for BM innovation for $\mathrm{CE}$ and/or sustainability, finding opportunities to seize synergies from the intersection of both streams. They acknowledge resource efficiency and economic growth at the intersection of $\mathrm{CE}$ and sustainable development approaches.

Geissdoerfer et al. [17], proposed a different framework, combining the discussions on sustainable development, CE, circular supply chain management and CBMs. These authors show how different CBMs are driving the circular supply chain in different loops: closing loops, slowing loops, intensifying loops, narrowing loops, and dematerializing loops. These circular business models vary in complexity according to the circular supply chain and the value proposition.

Their framework clearly identifies the elements (economic, environmental and social goals, proactive stakeholder management, and long-term perspective) on which circularity and sustainability rely. These aspects reinforce that the triple bottom line approachfocused on a sustainability based on economic, environmental and social pillars [13] - is relevant, but not sufficient for circular or sustainable BMs. A broad and proactive approach on stakeholders and a long-term perspective to complement short termed ones are also crucial factors for successful sustainable businesses.

Geissdoerfer et al. [17] develop evidence on the relationship between sustainable development and the CE. The connection between these perspectives is still open for discussion. On the one hand, $\mathrm{CE}$ can be assumed as one possible alternative, among others, to reach the goal of sustainable development. On the other, if sustainable development is becoming a very broad and sometimes intangible concept, the CE can become a more tangible way to organize society and its economic system. The objective of this discussion is to show the overlapping area between the concepts (Figure 4). 


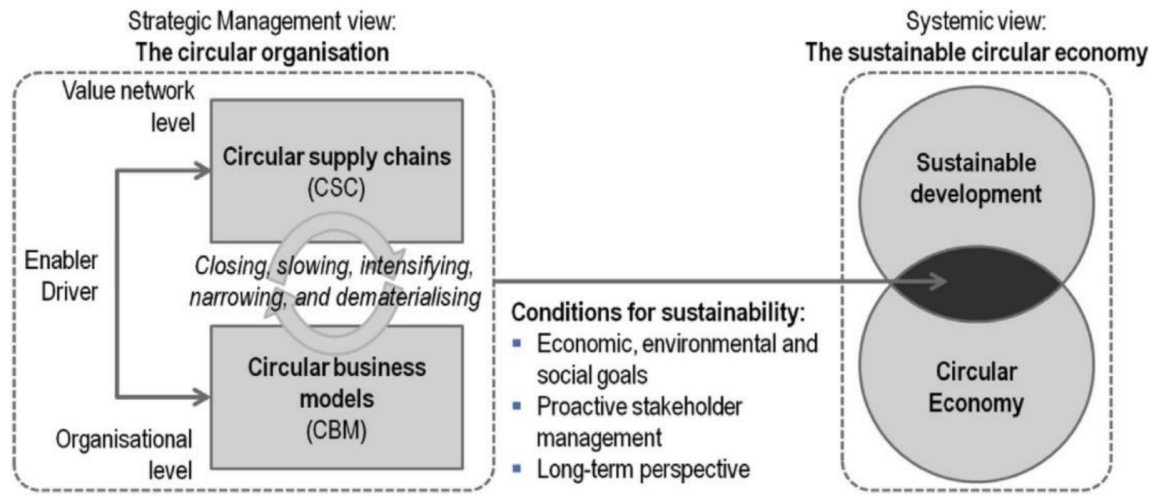

Figure 4. Geissdoerfer et al.'s Framework (2018). Source: [17]

On the basis of this literature review, which identified the quest of sustainability and the principles of $\mathrm{CE}$ within multiple understandings of the $\mathrm{BM}$, the authors propose a CBM for analyzing the adaptive re-use of the cultural heritage ecosystem as a living system (Figure 5).

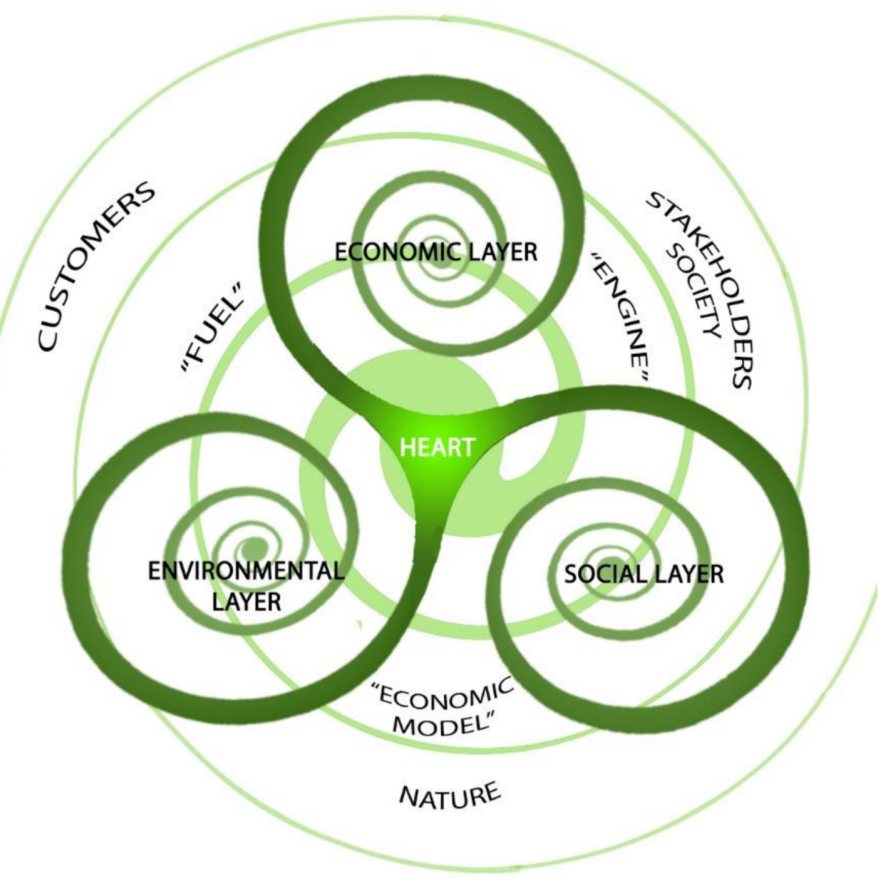

Figure 5. Proposed circular BM (CBM) for the adaptive re-use of cultural heritage ecosystem. Source: authors' own elaboration.

In Figure 5, the nine traditional components of the traditional BM have been clustered in the second level to render the living nature of cultural heritage into an ecosystem perspective: the Heart (value proposition), Fuel (customer relationship, customer segments, and channels), the Engine (key resources, key activities, and key partnerships), and the economic model (cost structure and revenue streams). The three layers (economic, social, and environmental) of the Triple Layered Business Model by Joyce and Paquin [129] are interpreted in a dynamic or evolutionary perspective to make the horizontal and vertical coherence characterizing this CBM clearer visually. These components are interdependently connected, affect each other, and adapt to the changing context by the internal dynamic of adapting, learning, and memory integration of information, experience, and knowledge processes. 
This canvas, which reflects the circular model, includes the notion of complex value (i.e., complex social value) in the long term, that is, to assume also the needs of the future generations and to generate services and experiences. Specifically, this CBM stimulates the production of system complementarities, that is, of synergies and possible symbioses in the cultural ecosystem. It means that cultural activities will support activities in other industrial sectors directly and indirectly. A better consumption of cultural heritage can generate several positive externalities on the well-being of the community and society, for example, from mitigating the negative effects of aging or reinforcing social cohesion, or by stimulating social and environmental awareness, which will develop the collaborative capacity of stakeholders to the transition toward a decarbonized economy. This canvas has to assume the de-materialization of products (instead of property) as the future new demand, and it relies on the digital connections which become absolutely strategic for its successful implementation.

Specifically, this new business model has a strong relational nature of:

- $\quad$ Key partners, i.e., with whom to produce, with which networks;

- How to produce (key activities, resources and technologies);

- Which values to create (value proposition);

- With which relationships to connect production and consumption (consumer relationships);

- $\quad$ For whom to produce (costumers/users/society/nature);

- With which revenues to produce.

This CBM has to satisfy the needs of different categories: entrepreneurs, customers, stakeholders, society (including future generations), and nature (for example, through nature-based solutions). It stimulates a manager's desire to create a "win-win-win" situation in terms of revenue and for the community and nature, considered as key infrastructure. A consensus can be found thanks to an internal dynamic process that occurs within the CBM (Figure 6). This consensus relies on the acceptance of the existence of different kinds of actors involved, their values, and needs, and of different dimensions mobilized in the business process to reach solutions characterized by a positive sum. Owing to this consensus, the CBM can explain not just value creation and value capturing as other BMs do, but also value distribution, which is fundamental in CE logic.

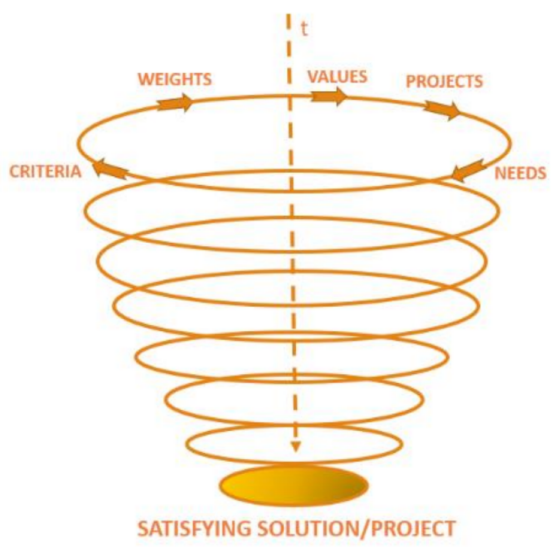

Figure 6. Dynamic process toward positive sum project. Source: authors' adaptation from [133].

This CBM for managing heritage assets as a living organism should incorporate both instrumental and intrinsic values. These values should be all considered in planning and management choices about adaptive reuse. Moreover, the new BM should address the following kinds of questions: is the "value of Nature" — suggested by WHO [23] incorporated in the value proposition? If yes, how? Are the intrinsic values of existing ecosystems conserved or damaged with the introduction of new use values and transformations? Is the intrinsic value of cultural/natural heritage promoted, reduced, or 
compromised? Is the solution proposed coherent with the memory and therefore with the intrinsic value of the system? To what extent is there value for the community with the new functions? Are the impacts of the adaptive management coherent or in conflict with the intrinsic values?

The adoption of this CBM stimulates a "value oriented" approach for managers, entrepreneurs, stakeholders, and consumers. Furthermore, this canvas has to encourage the manager to embrace the social objective, going beyond the maximization of profit toward creating value for the society. Therefore, this CBM aims to create, capture, and distribute value in the different layers considered.

A comprehensive canvas is not represented by the aggregation of the three different layers (economic, environmental, and social), but by its capacity to correlate them into an integrated evolutionary scheme. Therefore, this CBM supports the adaptive reuse of cultural heritage as interpreted in evolutionary economics (Figure 7).

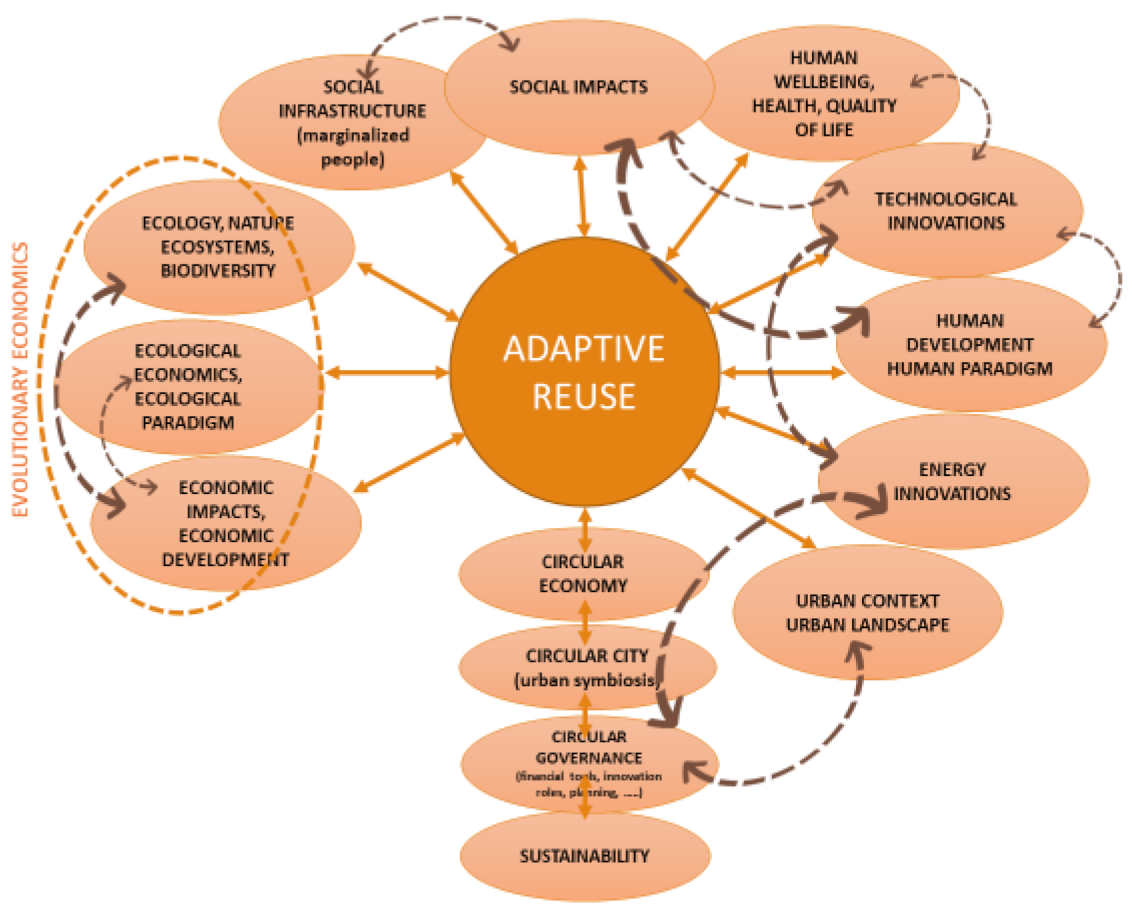

Figure 7. Evolutionary economics, adaptive reuse, and sustainability. Source: Authors' adaptation from Clic Project (2020).

Evaluation processes in CBM management can simplify choice processes and enable the transformation of ecological and social impacts into economic ones. In this way, communication between all involved subjects can become much more effective.

Digital technologies play a relevant role as they can be the connectors that implement the circular model. First, the transition from the production of goods to the creation of online business platforms requires the harnessing of digital technologies. This new online business pattern implies that the value created is no longer in the products themselves but rather in the relationships developed between producers and consumers. This can help fully deploy the CBM's potential through suitable connections and digital infrastructures. Second, digital technologies can not only improve the resilience of ecosystems of more fragile social groups (young, aged, etc.,) but also facilitate the alignment of supply and demand, the creation of a local digital community, etc. 


\section{The Matera Case Study \\ The Matera Landscape's Intrinsic Value}

We decided to apply our theoretical framework to an Italian case study, which is relevant in our perspective. Matera, a medium size city in the South of Italy and European Capital of Culture in 2019, highlights in its history some forms of CE. The scarcity of resources, the need to appropriately use them, and the control of the sun and wind energy have driven the organization of the Sassi of Matera. The Sassi of Matera is a long-lasting example of the ability to create architectures and cities with few means and limited local resources. The difficult situation in which Matera was located pushed the population to adopt "new" strategies of how to survive in the territory with continuous adaptations.

The water conservation system is a good example of circularity to reduce the waste of this resource. Taking advantage of the available natural tufa rock (a magmatic and workable rock), excavation has allowed for the creation of ducts and tanks for water supply to the houses of the typical stones (Sassi). Cisterns were either private or supplied to the whole neighborhood. Because of the extreme poverty characterizing the city, families were forced to eliminate or minimize any form of waste, instead recycling and reusing it [6]. Houses were developed in the rock with deep underground rooms opening onto terraces and hanging gardens.

The terraces and shelters of transhumant agropastoralism-the archaic methods for storing products, for collecting water and forcing it into the garden, and the clearing in front of the cave to the cistern (the fulcrum of the neighborhood organization)constituted the still identifiable circular matrix on which the urban fabric of the city of Matera grew [134,135], ensuring conditions of substantial systemic resilience over time. The cisterns, in fact, which far exceeded the inhabited caves and the need for drinking water, testify to the successful organization of the agricultural gardens carved in Matera. Subsequently, the need for housing led to space being taken from agriculture and many of the cavities of the cisterns-used only for domestic water-were transformed into houses.

The sun's energy oriented and shaped the design and use of its spaces. Together with the use of caves to collect water by gravity, it determined that its course would not be completely horizontal, but on a slope as it progresses deeper. The inclination of the path between the underground spaces allows solar rays to penetrate deeper and facilitates aeration. It is possible that the excavation itself was carried out following the projection of the sun on the bottom of the internal walls [136]. Every surface was exploited to cultivate gardens, anticipating urban agriculture (a characteristic of the $\mathrm{CE}$ ). Thus, Matera is the city of secular co-evolution between man, nature, and culture. The total integration among the natural framework, the immense excavation work and the in-view constructions makes the Sassi of Matera an extraordinary example of symbiosis between the site and human intervention.

Matera is not only a city exemplary in the sense of the ecological economy in which the economy has for centuries been incorporated into the more general context of ecology (i.e., the economy of nature), but it is also a city of social ecology and cultural ecology. Neighborhood relations have given spatial shape to the types of buildings built and their organization around common living spaces (open spaces, gardens, etc.,). The symbiotic relationship between man and nature finds a reflection in the co-evolutive, co-operative, and solidary relationships among different subjects and in the creation of specific microcommunities. It is the city where the triangular relationship between nature, society, and culture represents the very foundation of the value of its resulting landscape.

These inter-relationships among nature, society, and culture have produced a specific landscape where each single component interacts with and is interdependent from the others. In other words, the Matera landscape expresses the circular or reciprocal relationship between nature and society through culture. This landscape is the reflection of an absolutely unique urban process organization and its hidden order: its "intrinsic value".

The "intrinsic value" is the essential value that comes from being able to express elements of permanence in the continuous urban and territorial dynamic. This "intrinsic 
value" emerges for example in religious architecture and heritage (i.e., convents, abbeys, cathedrals, sacred sites) and survives even when a cultural asset is no longer used. It expresses creativity, diversity, and power, and highlights the essential structure of a site which in its turn structures the context in a reciprocal relationship. One outcome of "intrinsic value" is the beauty of the site or landscape itself, which is not only linked to the balance of the components but to the harmony of the whole system, as in a living system [21,137].

Being the result of a social "construction" of meaning, the interpretation and evaluation of "intrinsic value" requires the participation of the local community. Therefore, a solely neo-positivist approach is not possible. Instead, a participatory communicative dialogic process [138] is required. This can also lead to the identification of different coexisting "intrinsic values", even if characterized by common elements.

The role of the "intrinsic value" of the Matera landscape is to drive the new development of the city: of its sites, its historical center, and the surrounding territory. It also contributes to the identification of a direction for its use and management combining in a satisfying solution the evolutionary and historic adaptation capacity to change with its memory. In this sense, by offering a perspective to new local valorization and regeneration strategies, the intrinsic value is the foundation on which to articulate any new use value (or combination of multiple use values) connected to a new project or strategy. In this way, the new project is in continuity with its territorial history and offers the "energy" for a creative synthesis and hybridization between memory and innovation.

The "intrinsic value" also offers limitations in "managing change" [139]. The ICOMOS Burra Charter $[1,140]$ first initiated a discussion of intrinsic value in the conservation of cultural heritage. In ecological economics, the notion of intrinsic value is linked to the self-regeneration capacity of a system: to its self-organization capacity, self-sustainability, and self-sufficiency linked to the "glue" or primary value [141]. It is the foundation of instrumental economic values. The system receives from its surrounding context wealth, materials, waste from other natural systems, etc., that are processed through loops. In this way, the system can also sustain other elements: it is "useful" in ecological, social, and economic dimensions. The "in and of itself" value of the Sassi landscape can be expressed first of all through indicators reflecting the intensity of the circular processes in the urban flow of water, energy, materials, etc. In this perspective, this value is configured as a component of the "intrinsic value" to be conserved and valorized in the regeneration of Matera because it itself represents the memory of the urban system. This "intrinsic value" has given a physical-spatial form to the urban structure and has configured its specific identity and landscape. This generates in turn economic, social, environmental, and cultural values with complex networks between causes and effects. This circular organization has nurtured and nourished people and activities for centuries. The intrinsic value is therefore the hidden organizational order that ties together all the components of a city or site, from which, like in natural ecosystems, its harmony is reflected in its identity and beauty [137].

From the above, it is clear that any solutions for the development of the city of Matera should be coherent with its intrinsic value, that is, with its ancient structural organizational order and circular systemic structure. For example, circular hubs of entrepreneurship and start-ups should be proposed as "integrated productive environments" [142] or as a "loci of condensation" for a new circular city development. These circular hubs or clusters should be characterized by systemic interdependencies, complementarities, and symbiosis between private, public, and social subjects. These symbioses should pay attention to the relations between the city and agricultural and agro-ecological activities in the non-urban territory. Circular development solutions are thus required not only by the European Green Deal, but, first of all, by Matera's long history, identity, and intrinsic value. 


\section{Matera's CBM in Managing the Heritage Ecosystem as a Living Organism}

The CBM proposed in Section 5 is characterized by the production of many intangible services, supported by the need to avoid the underutilization of existing resources (for example, the holiday apartments used only for $5-10 \%$ of their useful life-time, etc.,) and of sharing services between many users. This will imply a reduction of costs and prices, which in turn generates new demand, in a circular process that tends to sustain itself over time.

This CBM in the adaptive reuse is characterized by some concrete elements:

- It is based on a multidimensional approach;

- It relies on the ability to incorporate external effects;

- It is based on the centrality of the collaborative, coordinating, and synergistic perspective of the different subjects involved, including institutional ones, through new forms of agreements, contracts, or partnerships;

- $\quad$ It is a long-term model;

- It attributes importance to the values of use and to intrinsic value, not only to exchange values;

- It is characterized by a systemic logic, which takes into account multiple interdependencies;

- It is designed to avoid or minimize different forms of waste and the underutilization of resources and capital;

- It is attentive to all technological innovations, and in particular to energy and digital technologies, to improve the overall productivity;

- It pays attention to the use of local resources (material, financial, energy, human, social, ecological, etc.);

- It supports the production of intangible services in place of material goods;

- It enhances and ensures long-term relationships with buyers and users;

- It uses fewer natural resources;

- It pays attention to the flow of ecosystem services that are derived from natural resources and that support human activities;

- It is attentive to the circular closure of processes, as Mother Nature teaches, so that each output is reused as input for other goods and services;

- It considers the well-being (and the variation of well-being) of the subjects involved.

In Section 6 we introduced the Matera case as a good practice example of circular organization and circular business models. Different types of symbioses characterize Matera and its unique landscape. In its intrinsic value and specific organizational structure, one can find:

- A symbiosis between the historical center and modern city;

- A symbiosis between the city and agricultural/forest territory;

- A symbiosis between the city and urban cores/outside villages;

- A symbiosis between the city and innovative productive activities;

- A symbiosis between productive activities;

- An agro-forestry-livestock symbiosis.

These symbioses represent the image of the ideal circular city. They can be mobilized in order to improve human-centered activities. Let us take the example of tourism activities in Matera (Figure 8). They should be designed to evolve toward circular tourism [143] and to create interdependencies with many activities. 


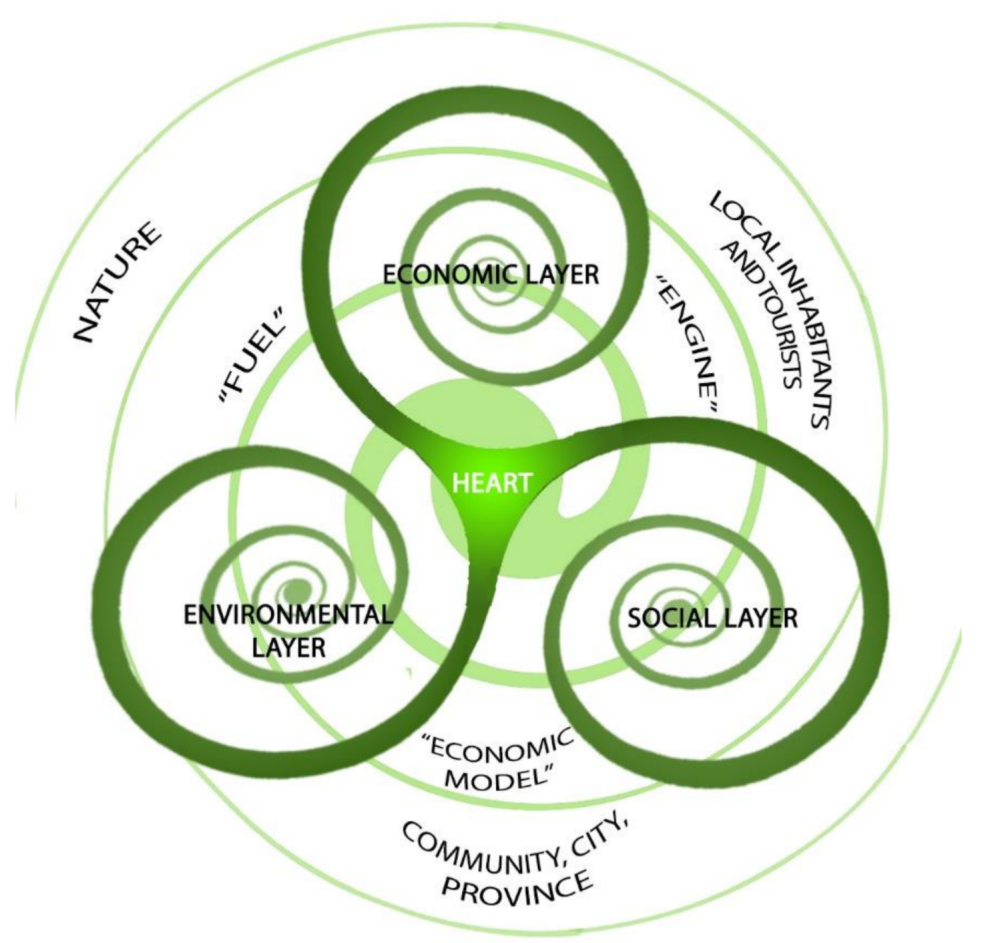

Figure 8. Matera's CBM for touristic activities in the ecosystem perspective. Source: authors' own elaboration.

The tourism CBM in Figure 8 should minimize the resources needed to produce services and therefore provide benefits also to the whole city and to nature, reducing waste, emissions, and environmental impacts. The current entrepreneurship risk should include new risks linked to climate change impact engine. All touristic activities should be implemented to valorize the specific cultural heritage assets. To be effective in a sustainable and circular perspective, forms of circular tourism should be promoted in which the negative impacts and externalities generated by tourists can be reduced. This will improve the overall metabolism of the ecosystem (renewable energy, consumption of local agro-foodlivestock products, etc.,) and, at the same time, create forms of human-centered tourism. These forms of human-centered and circular tourism will be relevant to enhance the spirit of the place (its genius loci), to introduce more integration in the cultural services, cooperation with other actors and sectors, and to identify co-generated and shared solutions which do not "extract" value but preserve and guarantee values as well as the needs of future generations. These co-generated and shared solutions may avoid concentrations in the use of areas already known and exploited as they redistribute tourism to territory outside the city (for example, linking the center with the many rural abandoned churches) and link tourism with cultural and creative activities.

In Figure 8, the key partners are represented by all agents that can play a role in developing and supporting these touristic activities. The fuel clusters the customer segment (tourists, the local population, future generations, and nature), the customer relationship (participative forms of animating and supporting cultural heritage through touristic activities) and the channel (traditional and more innovative methods such as new technologies). These three components should be analyzed in a multidimensional perspective that takes into account the three different layers. The effort required is to analyze them at the same time: they are strictly interconnected in an interdependent-not dependent-structure. Finally, the economic model (revenue streams generated by the human-centered touristic activities and a cost structure that sustains it) is relevant not just in the economic layer but also in the environmental and social layer. This new and more appropriate economic approach — which goes beyond the maximization of profit—will create value for society and sustain nature through the iterative processes of identifying the most satisfying solution. If 
visionary entrepreneurs embrace this circular approach in their BM, they will be able to attain value in different dimensions (layers) by contributing to the sustainable social and environmental objectives. As we have seen, sustainable value can be created for customers only by generating value for a broader range of stakeholders and subjects.

\section{Conclusions}

It is possible to transfer the concept of intrinsic value from natural ecosystem heritage to cultural heritage. This notion of intrinsic value is not an infringement but a way to promote more effective choices. The city of Matera has been proposed as an example of tangible and intangible intrinsic value. Other examples of heritage's intrinsic value are visible in some religious monuments, around which a specific and irreplicable "force field" is built. This attractive "intrinsic value" has given cultural heritage its authentic vitality and shows an unitive capacity for activities and persons. This can be understood as a complementary and reciprocal structure and a set of behaviors and actions, as found in natural ecosystems, where a specific attractive capacity involves and unites different components: as a specific unitive capacity. The reused cultural heritage attracts people and thus generates or regenerates a heritage community.

In this perspective, its capacity is similar to the intrinsic value of natural ecosystems: they have a unitive or "glue "capacity. The set of anthropocentric instrumental and intrinsic values represents the overall systemic value of these cultural sites or historic urban landscapes. They should be assessed [28] and managed with care and wisdom [144]. The assessment of the intrinsic value of cultural heritage is useful in the choice of new use values for heritage assets. Furthermore, the integration of an approach based on instrumental values (assessed with economic tools) and intrinsic values may improve more choices in planning and management processes. This integrates quantitative approaches of a positivist nature (such those of natural and economic sciences) with approaches of constructivist/interpretative nature (non-quantitative) used by human sciences (i.e., anthropology, history, sociology, etc.,) [145]. This should lead to sustainable BMs being able to fully realize the $\mathrm{CE}$, contributing to the sustainable development of the ecosystem as a whole.

The assessment of the intrinsic value of Matera as a circular structural order is a recommendation for others to design and plan development strategies based on circular economic and territorial models. These circular territorial solutions should be characterized by a co-evolutive dynamic between man-made complex adaptive system and natural complex adaptive systems. Circular territorial projects are characterized first of all by place-led and nature-led solutions. Thus, they can contribute to re-generative ecosystem services, as happens in nature: they are in fact designed, organized, and managed as "vital natural organism[s]" able to co-evolve with others.

The ideal circular and nature-led territorial solutions are oriented to imitate how trees and the forest function: they should become self-sustainable, use renewable energy, reuse rainwater and natural materials, and avoid any waste. They are capable of continuous adaptations to a changing context because a co-evolutionary approach is embedded in their management and planning, just like in nature, where adaptation means adjustments and learning from failure.

The circular territorial project evokes an "adaptive and flexible system" able to organize and re-organize systemic complementarities. It does so by increasing cooperation and coordination with public, private, and social subjects through synergies and symbioses. It embraces the use of innovative technologies and materials (digital, energy, bio and nano technologies, artificial intelligence, IoT, automatization, data management etc.,) in residential services, productive and industrial sectors, agriculture, tourism etc. It does so to enhance productivity and to reduce the waste of different forms of capital, thereby actively reducing social disparities, poverty, marginality, and other exclusions. CBMs help to identify adaptive and creative solutions in heritage, thus imitating the creative and sustainable capacity of nature. 
Cultural heritage assets are a way to regenerate a "connective infrastructure" [146], not only in society but also in relationship to nature.

Author Contributions: Conceptualization L.F.G. and M.V.; methodology: L.F.G. and M.V.; investigation: L.F.G. and M.V.; writing—original draft preparation, L.F.G. and M.V.; writing—review and editing: L.F.G. and M.V.; project administration: L.F.G. All authors have read and agreed to the published version of the manuscript.

Funding: This research received no external funding.

Institutional Review Board Statement: Not applicable.

Informed Consent Statement: Not applicable.

Conflicts of Interest: The authors declare no conflict of interest.

\section{References}

1. Australia ICOMOS. The Australia ICOMOS Charter for Places of Cultural Significance. Available online: http:/ /amagawa.org. au/wp-content/uploads/2014/12/The-Burra-Charter-2013.pdf (accessed on 12 March 2021).

2. European Commission. The European Green Deal. Eur. Comm. 2019. [CrossRef]

3. Mossetto, G.; Vecco, M. Economia del Patrimonio Monumentale; Franco Angeli: Milano, Italy, 2002.

4. Vecco, M. Value and Values of Cultural Heritage. In Cultural Heritage: A Research Anthology; Reynolds, L., Campelo, A., Lindgreen, A., Beverland, M.B., Eds.; Routledge: London, UK, 2018.

5. Zeleny, M. Optimizing Given Systems Vs. Designing Optimal Systems: The De Novo Programming Approach. Int. J. Gen. Syst. 1990. [CrossRef]

6. Fusco Girard, L. Implementing the Circular Economy: The Role of Cultural Heritage as The Entry Point. Which Evaluation Approaches? BDC Boll. Del Cent. Calza Bini 2019, 19, 245-277. [CrossRef]

7. CHCFE Consortium. Cultural Heritage Counts for Europe Full Report. Available online: https:/ /www.digitalmeetsculture.net/ article/cultural-heritage-counts-for-europe-final-report/?upm_export=pdf (accessed on 12 March 2021).

8. Costanza, R.; D’Arge, R.; De Groot, R.; Farber, S.; Grasso, M.; Hannon, B.; Limburg, K.; Naeem, S.; O’Neill, R.V.; Paruelo, J.; et al. The value of the world's ecosystem services and natural capital. Nature 1997. [CrossRef]

9. Jackson, T. Prosperity without Growth: Economics for a Finite Planet; Earthscan: London, UK, 2009.

10. WCED. Report of the World Commission on Environment and Development: Our Common Future Acronyms and Note on Terminology Chairman's Foreword. Available online: https://sustainabledevelopment.un.org/content/documents/5987ourcommon-future.pdf (accessed on 12 March 2021).

11. Meadows, D.H.; Meadows, D.L.; Randers, J.; Behrens, W., II. The Limits to Growth: A Report for the Club of Rome's Project on the Predicament of Mankind, 5th ed.; Universe Books: New York, NY, USA, 1972.

12. Meadows, D.; Randers, J.; Meadows, D. A Synopsis: Limits to Growth- 30 Year Update. Available online: http://www. businessperformance.org/sites/default/files/donellameadows.org-A_Synopsis_Limits_to_Growth_The_30Year_Update.pdf (accessed on 12 March 2021).

13. Elkington, J. Cannibals with Forks: The Triple Bottom Line of 21st Century Business; John Wiley and Sons: London, UK, 1997.

14. Geissdoerfer, M.; Savaget, P.; Bocken, N.M.P.; Hultink, E.J. The circular economy: A new sustainability paradigm? J. Clean. Prod. 2017, 143, 757-768. [CrossRef]

15. Andersen, M.S. An introductory note on the environmental economics of the circular economy. Sustain. Sci. 2007, 2, 133-140. [CrossRef]

16. Su, B.; Heshmati, A.; Geng, Y.; Yu, X. A review of the circular economy in China: Moving from rhetoric to implementation. J. Clean. Prod. 2013. [CrossRef]

17. Geissdoerfer, M.; Morioka, S.N.; de Carvalho, M.M.; Evans, S. Business models and supply chains for the circular economy. J. Clean. Prod. 2018. [CrossRef]

18. Stahel, W.R. The Product Life Factor. An Inquiry into the Nature of Sustainable Societies: The Role of the Private Sector; Houston Area Research Cente: Houston, TX, USA, 1982.

19. Kirchherr, J.; Reike, D.; Hekkert, M. Conceptualizing the circular economy: An analysis of 114 definitions. Resour. Conserv. Recycl. 2017, 127, 221-232. [CrossRef]

20. Fusco Girard, L. The circular economy in transforming a died heritage site into a living ecosystem, to be managed as a complex adaptive organism. Aestimum 2020. [CrossRef]

21. Zelený, M.; Hufford, K.D. The application of autopoiesis in systems analysis: Are autopoietic systems also social systems? Int. J. Gen. Syst. 1992, 21, 145-160. [CrossRef]

22. Geddes, P. Cities in Evolution: An Introduction to the Town Planning Movement and to the Study of Civics; Williams \& Norgate: London, UK, 1915.

23. WHO Manifesto for a Healthy Recovery from COVID-19. Available online: https://www.who.int/docs/default-source/climatechange/who-manifesto-for-a-healthy-and-green-post-covid-recovery.pdf (accessed on 12 March 2021). 
24. Fusco Girard, L.; Nocca, F. Climate change and health impacts in urban areas: Towards hybrid evaluation tools for new governance. Atmosphere 2020, 11, 1344. [CrossRef]

25. Fusco Girard, L. Risorse Architettoniche e Culturali: Valutazioni e Strategie di Conservazione; Franco Angeli: Milano, Italy, 1987.

26. Fusco Girard, L.; Nijkamp, P. Le Valutazioni per lo Sviluppo Sostenibile Della Città e del Territorio; Franco Angeli: Milano, Italy, 1997.

27. Costanza, R. Ecological Economics. The Science and Management of Sustainability; Columbia University Press: New York, NY, USA, 1992.

28. Faber, M.; Manstetten, R.; Proops, J.L.R. On the conceptual foundations of ecological economics: A teleological approach. Ecol. Econ. 1995. [CrossRef]

29. Turner, R.K. Sustainable Environmental Economics and Management: Principles and Practice; Belhaven Press: London, UK, 1993; ISBN 978-0470221631.

30. de Groot, R.; Brander, L.; van der Ploeg, S.; Costanza, R.; Bernard, F.; Braat, L.; Christie, M.; Crossman, N.; Ghermandi, A.; Hein, L.; et al. Global estimates of the value of ecosystems and their services in monetary units. Ecosyst. Serv. 2012. [CrossRef]

31. Ehrlich, P.; Roughgarden, J. The Science of Ecology. In The Science of Ecology; Crowell-Collier: New York, NY, USA, 1987.

32. Gren, I.M.; Folke, C.; Turner, K.; Batemen, I. Primary and secondary values of wetland ecosystems. Environ. Resour. Econ. 1994. [CrossRef]

33. Dasgupta, P. Final Report-The Economics of Biodiversity: The Dasgupta Review. Final Report of the Independent Review on the Economics of Biodiversity led by Professor Sir Partha Dasgupta. 2021. Available online: https:/ /www.gov.uk/government/ publications / final-report-the-economics-of-biodiversity-the-dasgupta-review (accessed on 1 January 2021).

34. Turner, R.K. Speculations on Weak and Strong Sustainability; CSERGE: Norwich, UK, 1992.

35. Fisher, B.; Turner, R.K.; Burgess, N.D.; Swetnam, R.D.; Green, J.; Green, R.E.; Kajembe, G.; Kulindwa, K.; Lewis, S.L.; Marchant, R.; et al. Measuring, modeling and mapping ecosystem services in the Eastern Arc Mountains of Tanzania. Prog. Phys. Geogr. 2011. [CrossRef]

36. Ruskin, J. Unto This Last; Cornhill Magazine: London, UK, 1860.

37. Riegl, A. Entwurf einer Gesetzlichen Organisation der Denkmalpflege in Ősterreich, Wien: Bundesdenkmalamt Österreich (Progetto di una organizzazione legislativa della conservazione in Austria-Il culto moderno dei monumenti), trad. It. In Alois Riegl: Teoria e Prassi della Conservazione dei Monumenti; Scarrocchia, S., Ed.; Clueb: Bologna, Italy, 1903; pp. 171-236.

38. Framarin, C.G. Hinduism and environmental ethics: An analysis and defense of a basic assumption. Asian Philos. 2012. [CrossRef]

39. Vecco, M. Genius loci as a meta-concept. J. Cult. Herit. 2020. [CrossRef]

40. Fusco Girard, L.; Vecco, M. Genius loci: The evaluation of places between instrumental and intrinsic values. BDC Boll. Del Cent. Calza Bini 2019, 19, 473-495. [CrossRef]

41. Callicott, J.B. Explicit and implicit values. In The Endangered Species Act at Thirty: Conserving Biodiversity in Human-Dominated Landscapes; Scott, J., Goble, D., Davis, F., Eds.; Island Press: Washington, DC, USA, 2006; Volume II, pp. 36-48.

42. Elliot, R. Intrinsic Value, Environmental Obligation and Naturalness. Monist 1992. [CrossRef]

43. Charola, A.E.; Baer, N.S.; Snickars, F. Rational Decision-Making in the Preservation of Cultural Property. Stud. Conserv. 2002. [CrossRef]

44. Throsby, D. Cultural Capital and Sustainability Concepts in the Economics of Cultural Heritage. In Assessing the Value of Cultural Heritage; de la Torre Getty, M., Ed.; Conservation Institute: Los Angeles, CA, USA, 2002; pp. 101-117.

45. Cassar, M. Places and Stuff: Is it Only the Language of Conservation that is Changing? In Conservation of Historic Buildings and Their Contents: Addressing the Conflicts; Watt, D., Colston, B., Eds.; Don Head Publishing and De Montfort University: Shaftesbury, UK, 2003; pp. 41-51.

46. Taylor, J. Intergenerational justice: A useful perspective for heritage conservation. CeROArt 2013. [CrossRef]

47. Vecco, M.; Montagner, E.; Srajar, A. Genius loci: Between handcrafts, cultural heritage and local development. Eur. J. Cult. Manag. Policy 2020, 10, 64-75.

48. Norberg-Schulz, C. Genius Loci: Towards a Phenomenology of Architecture; Rizzoli: Milano, Italy, 1980.

49. Rea, A.W.; Munns, W.R. The value of nature: Economic, intrinsic, or both? Integr. Environ. Assess. Manag. 2017, 13, 953-955. [CrossRef]

50. Drucker, P. The Practice of Management; Allied Publishers: New Delhi, India, 1955.

51. Zott, C.; Amit, R.; Massa, L. The business model: Recent developments and future research. J. Manag. 2011, 37, 1019-1042.

52. Osterwalder, A.; Pigneur, Y.; Smith, A.; Movement, T. Business Model Generation: A Handbook for Visionaries, Game Changers, and Challengers; John Wiley \& Sons: Hoboken, NJ, USA, 2010; ISBN 9780470876411.

53. zu Knyphausen-Aufsess, D.; Meinhardt, Y. Rivisiting strategy: Ein Ansatz zur Systematisierung von Geschaftsmodellen. In Zukunftige Geschaftsmodelle; Bieger, T., Bickhoff, N., Caspers, R., zu Knyphausen-Aufseß, D., Reding, K., Eds.; Springer: Berlin, Germany, 2002; pp. 63-89.

54. Massa, L.; Tucci, C.L.; Afuah, A. A critical assessment of business model research. Acad. Manag. Ann. 2017, 11, 73-104. [CrossRef]

55. Berger, P.; Luckmann, T. The Social Construction of Reality, a Treatise in the Sociology of Knowledge; Penguin: London, UK, 1966.

56. Nielsen, C. A brief history of the business model concept. In Business Models: Networking, Innovating and Globalizing; Nielsen, C., Lund, M., Eds.; BookBoon.com/Ventus Publishing: Copenaghen, Danmark, 2012; pp. 26-33.

57. Al-Debei, M.M.; Avison, D. Developing a unified framework of the business model concept. Eur. J. Inf. Syst. 2010. [CrossRef] 
58. Eriksson, H.-E.; Penker, M. BOOK—Business Modeling With UML: Business Patterns at Work; John Wiley \& Sons: New York, NY, USA, 2000.

59. Timmers, P. Business Models for Electronic Markets. Electron. Mark. 1998. [CrossRef]

60. Beattie, V.; Smith, S.J. Value creation and business models: Refocusing the intellectual capital debate. Br. Account. Rev. 2013. [CrossRef]

61. Dubosson-Torbay, M.; Osterwalder, A.; Pigneur, Y. E-business model design, classification, and measurements. Thunderbird Int. Bus. Rev. 2002. [CrossRef]

62. Mahadevan, B. Business models for Internet-based e-commerce: An anatomy. Calif. Manag. Rev. 2000, 42, 55-69. [CrossRef]

63. Shafer, S.M.; Smith, H.J.; Linder, J.C. The power of business models. Bus. Horiz. 2005. [CrossRef]

64. Teece, D.J. Business models, business strategy and innovation. Long Range Plann. 2010. [CrossRef]

65. Biloslavo, R.; Bagnoli, C.; Edgar, D. An eco-critical perspective on business models: The value triangle as an approach to closing the sustainability gap. J. Clean. Prod. 2018. [CrossRef]

66. Alt, R.; Zimmermann, H.-D. Preface: Introduction to Special Section-Business Models. Electron. Mark. 2001. [CrossRef]

67. Johnson, M.W.; Christensen, C.M.; Kagermann, H. Reinventing your business model. Harv. Bus. Rev. 2008, 86, 50-59.

68. Morris, M.; Schindehutte, M.; Allen, J. The entrepreneur's business model: Toward a unified perspective. J. Bus. Res. 2005. [CrossRef]

69. Seddon, P.B.; Freeman, P. The Case for Viewing Business Models as Abstractions of Strategy. Commun. Assoc. Inf. Syst. 2004. [CrossRef]

70. Demil, B.; Lecocq, X. Business model evolution: In search of dynamic consistency. Long Range Plann. 2010. [CrossRef]

71. Hamel, G. Leading the Revolution: How to Thrive in Turbulent Times by Making Innovation a Way of Life; Harvard Business School Press: Boston, MA, USA, 2000.

72. Hedman, J.; Kalling, T. The business model concept: Theoretical underpinnings and empirical illustrations. Eur. J. Inf. Syst. 2003. [CrossRef]

73. Casadesus-Masanell, R.; Ricart, J.E. From strategy to business models and onto tactics. Long Range Plann. 2010. [CrossRef]

74. Magretta, J. Why business models matter. Harv. Bus. Rev. 2002, 80, 3-8.

75. Amit, R.; Zott, C. Value creation in e-business. Strateg. Manag. J. 2001. [CrossRef]

76. Chesbrough, $\mathrm{H}$. The role of the business model in capturing value from innovation: Evidence from Xerox Corporation's technology spin-off companies. Ind. Corp. Chang. 2002, 11, 529-555. [CrossRef]

77. George, G.; Bock, A.J. The Business Model in Practice and its Implications for Entrepreneurship Research. Entrep. Theory Pract. 2011. [CrossRef]

78. Aversa, P.; Furnari, S.; Haefliger, S. Business model configurations and performance: A qualitative comparative analysis in Formula One racing, 2005-2013. Ind. Corp. Chang. 2015. [CrossRef]

79. Baden-Fuller, C.; Haefliger, S. Business Models and Technological Innovation. Long Range Plann. 2013. [CrossRef]

80. Clauss, T. Measuring business model innovation: Conceptualization, scale development, and proof of performance. $R D$ Manag. 2017. [CrossRef]

81. Spieth, P.; Schneider, S. Business model innovativeness: Designing a formative measure for business model innovation. J. Bus. Econ. 2016. [CrossRef]

82. Zott, C.; Amit, R. La importancia de innovar en el modelo de negocio. Rev. Antig. Alumnos del IEEM 2010, 5, 65-70.

83. Johnson, M.W. Seizing the White Space: Business Model Innovation for Growth and Renewal; Harvard Business School Press: Boston, MA, USA, 2010.

84. Abdelkafi, N. Open Business Models for the Greater Good-A Case Study from the Higher Education Context. Die Unternehmung 2012. [CrossRef]

85. Massa, L.; Tucci, C.L. Business Model Innovation; Oxford University Press: Oxford, UK, 2014.

86. Schaltegger, S.; Hansen, E.G.; Lüdeke-Freund, F. Business Models for Sustainability: Origins, Present Research, and Future Avenues. Organ. Environ. 2016, 29, 3-10. [CrossRef]

87. Bocken, N.M.P.; de Pauw, I.; Bakker, C.; van der Grinten, B. Product design and business model strategies for a circular economy. J. Ind. Prod. Eng. 2016. [CrossRef]

88. Rosa, P.; Sassanelli, C.; Terzi, S. Circular Business Models versus circular benefits: An assessment in the waste from Electrical and Electronic Equipments sector. J. Clean. Prod. 2019, 231, 940-952. [CrossRef]

89. Ellen MacArthur Foundation. Growth Within: A Circular Economy Vision for a Competitive Europe. Available online: https:/ / www.ellenmacarthurfoundation.org/assets/downloads/circular-economy /Growth-Within-Report.pdf (accessed on 1 January 2021).

90. Charter, M. Circular Economy Business Models. Available online: https://research.ucreative.ac.uk/3270/1/MC\%20Paper.pdf (accessed on 1 January 2021).

91. Manninen, K.; Koskela, S.; Antikainen, R.; Bocken, N.; Dahlbo, H.; Aminoff, A. Do circular economy business models capture intended environmental value propositions? J. Clean. Prod. 2018. [CrossRef]

92. Mendoza, J.M.F.; Sharmina, M.; Gallego-Schmid, A.; Heyes, G.; Azapagic, A. Integrating Backcasting and Eco-Design for the Circular Economy: The BECE Framework. J. Ind. Ecol. 2017. [CrossRef] 
93. Schaltegger, S.; Lüdeke-Freund, F.; Hansen, E.G. Business cases for sustainability: The role of business model innovation for corporate sustainability. Int. J. Innov. Sustain. Dev. 2012. [CrossRef]

94. Smith, W.; Lewis, M. Toward a theory of paradox: A dynamic equilibrium model of organizing. Acad. Manag. Rev. 2011. [CrossRef]

95. Stubbs, W.; Cocklin, C. Conceptualizing a "sustainability business model". Organ. Environ. 2008. [CrossRef]

96. Bocken, N.; Short, S.; Rana, P.; Evans, S. A value mapping tool for sustainable business modelling. Corp. Gov. 2013. [CrossRef]

97. Geissdoerfer, M.; Vladimirova, D.; Evans, S. Sustainable business model innovation: A review. J. Clean. Prod. 2018, 198, 401-416. [CrossRef]

98. den Hollander, M.; Bakker, C. Mind the Gap Exploiter: Circular Business Models for Product Lifetime Extension. In Proceedings of the Electronic Goes Green 2016+: Inventing Shades of Green, Berlin, Germany, 7-9 September 2016; Fraunhofer IZM: Berlin, Germany, 2016; pp. 1-8.

99. Lozano, R. Envisioning sustainability three-dimensionally. J. Clean. Prod. 2008. [CrossRef]

100. Lozano, R. Creativity and organizational learning as means to foster sustainability. Sustain. Dev. 2014. [CrossRef]

101. Urbinati, A.; Chiaroni, D.; Chiesa, V. Towards a new taxonomy of circular economy business models. J. Clean. Prod. 2017. [CrossRef]

102. Bocken, N.M.P.; Mugge, R.; Bom, C.A.; Lemstra, H.J. Pay-per-use business models as a driver for sustainable consumption: Evidence from the case of HOMIE. J. Clean. Prod. 2018. [CrossRef]

103. Bocken, N.M.P.; Short, S.W.; Rana, P.; Evans, S. A literature and practice review to develop sustainable business model archetypes. J. Clean. Prod. 2014, 65, 42-56. [CrossRef]

104. Boons, F.; Lüdeke-Freund, F. Business models for sustainable innovation: State-of-the-art and steps towards a research agenda. J. Clean. Prod. 2013. [CrossRef]

105. França, C.L.; Broman, G.; Robèrt, K.H.; Basile, G.; Trygg, L. An approach to business model innovation and design for strategic sustainable development. J. Clean. Prod. 2017. [CrossRef]

106. Broman, G.I.; Robèrt, K.H. A framework for strategic sustainable development. J. Clean. Prod. 2017. [CrossRef]

107. Ritala, P.; Huotari, P.; Bocken, N.; Albareda, L.; Puumalainen, K. Sustainable business model adoption among S\&P 500 firms: A longitudinal content analysis study. J. Clean. Prod. 2018. [CrossRef]

108. Roome, N. Looking Back, Thinking Forward: Distinguishing Between Weak and Strong Sustainability. In The Oxford Handbook of Business and the Natural Environment; Bansal, P., Hoffman, A.J., Eds.; Oxford University Press: Oxford, UK, 2012 ; pp. 620-630.

109. van Bommel, K. Managing tensions in sustainable business models: Exploring instrumental and integrative strategies. J. Clean. Prod. 2018. [CrossRef]

110. Doherty, B.; Haugh, H.; Lyon, F. Social enterprises as hybrid organizations: A review and research agenda. Int. J. Manag. Rev. 2014. [CrossRef]

111. Haigh, N.; Walker, J.; Bacq, S.; Kickul, J. Hybrid organizations: Origins, strategies, impacts, and implications. Calif. Manage. Rev. 2015, 57, 5-12. [CrossRef]

112. Grassl, W. Business models of social enterprise: A design approach to hybridity. ACRN J. Entrep. Perspect. 2012, 1, 37-60.

113. Tukker, A. Eight types of product-service system: Eight ways to sustainability? Experiences from suspronet. Bus. Strateg. Environ. 2004. [CrossRef]

114. Mont, O.; Tukker, A. Product-Service Systems: Reviewing achievements and refining the research agenda. J. Clean. Prod. 2006, 14, 1451-1454. [CrossRef]

115. Wells, P.; Seitz, M. Business models and closed-loop supply chains: A typology. Supply Chain Manag. 2005. [CrossRef]

116. Wells, P. Economies of Scale Versus Small Is Beautiful: A Business Model Approach Based on Architecture, Principles and Components in the Beer Industry. Organ. Environ. 2016. [CrossRef]

117. Hawken, P.; Lovins, A.B.; Lovins, L.H. Natural Capitalism: Creating the Next Industrial Revolution; Earthscan Ltd.: New York, NY, USA, 2005.

118. Pauli, G. The Blue Economy. 10 Years, 100 Innovations, 100 Million Jobs. Report to the Club of Rome; Paradigm Publications: Taos, NM, USA, 2010.

119. McDonough, W.; Braungart, M. Cradle to Cradle: Remaking the Way We Make Things; North Point Press: New York, NY, USA, 2002.

120. Commoner, B. The Closing Circle: Nature, Man, and Technology; Knopf: New York, NY, USA, 1971.

121. Stahel, W.R. The Performance Economy; Palgrave MacMillan: Basingstoke, UK; New York, NY, USA, 2010.

122. Lyle, J.T. Regenerative Design for Sustainable Development; John Wiley \& Sons: New York, NY, USA, 1994.

123. Graedel, T.E.; Allenby Braden, R. Industrial Ecology; Prentice Hall: Englewood Cliffs, NJ, USA, 1995.

124. Benyus, J.M. Biomimicry; Harper Perennial: New York, NY, USA, 2002.

125. Lewandowski, M. Designing the business models for circular economy-towards the conceptual framework. Sustainability 2016, 8 , 43. [CrossRef]

126. Lüdeke-Freund, F.; Dembek, K. Sustainable business model research and practice: Emerging field or passing fancy? J. Clean. Prod. 2017. [CrossRef]

127. Lindsay Clinton, R.W. Model Behaviour 20 Business Model Innovations for Sustainibiliy. Available online: https://sun-connectnews.org/fileadmin/DATEIEN/Dateien/New/model_behavior_20_business_model_innovations_for_sustainability.pdf (accessed on 1 January 2021). 
128. Upward, A.; Jones, P. An Ontology for Strongly Sustainable Business Models: Defining an Enterprise Framework Compatible With Natural and Social Science. Organ. Environ. 2016. [CrossRef]

129. Joyce, A.; Paquin, R.L. The triple layered business model canvas: A tool to design more sustainable business models. J. Clean. Prod. 2016. [CrossRef]

130. Ritter, T.; Lettl, C. The wider implications of business-model research. Long Range Plann. 2018. [CrossRef]

131. Dentchev, N.; Rauter, R.; Jóhannsdóttir, L.; Snihur, Y.; Rosano, M.; Baumgartner, R.; Nyberg, T.; Tang, X.; van Hoof, B.; Jonker, J Embracing the variety of sustainable business models: A prolific field of research and a future research agenda. J. Clean. Prod. 2018. [CrossRef]

132. Pieroni, M.P.P.; McAloone, T.C.; Pigosso, D.C.A. Configuring New Business Models for Circular Economy: From Patterns and Design Options to Action. Available online: https://backend.orbit.dtu.dk/ws/portalfiles/portal/190069307/Configuring_new_ business_models_for_circular_economy_from_patterns_and_design_options_to_action.pdf (accessed on 1 January 2021).

133. Zeleny, M. Alla ricerca di un equilibrio cognitivo. In Estimo ed Economia Ambientale; Fusco Girard, L., Ed.; Franco Angeli: Milano, Italy, 1993; pp. 113-131.

134. Fusco Girard, L.; Nocca, F.; Gravagnuolo, A. Matera 2019 Capitale Europea della Cultura: Città della natura, città della cultura, città della rigenerazione. BDC Boll. del Cent. Calza Bini 2017, 17, 159-184. [CrossRef]

135. Fusco Girard, L.; Trillo, C.; Bosone, M. Matera, Città del Sistema Ecologico Uomo/Società/Natura: Il Ruolo della Cultura Per la Rigenerazione del Sistema Urbano/Territoriale; Giannini Publisher: Naples, Italy, 2019; ISBN 9788869061202.

136. Laureano, P. Giardini di Pietra. I Sassi di Matera e la Civiltà Mediterranea; Bollati Boringhieri: Torino, Italy, 2012.

137. Zeleny, M. Beauty, Quality, Armony. In Human System Management; World Scientific: Singapore, 1992; pp. 115-118.

138. Olejniczak, K.; Borkowska-Waszak, S.; Domaradzka-Widła, A.; Park, Y. Policy labs: The next frontier of policy design and evaluation? Policy Polit. 2020, 48, 89-110. [CrossRef]

139. UNESCO. Recommendation on Historic Urban Landscape. Available online: https://whc.unesco.org/uploads/activities/ documents/activity-638-98.pdf (accessed on 1 January 2021).

140. The Australia ICOMOS Charter for Places of Cultural Significance. Available online: https: / www.google.com.hk/url?sa=t\&rct= $\mathrm{j} \& \mathrm{q}=\& \mathrm{esrc}=\mathrm{s} \&$ source $=$ web\&cd =\&ved=2ahUKEwijxL2T4rHvAhXEMd4KHYFhChIQFjAHegQIBxAD\&url=https $\% 3 \mathrm{~A} \% 2 \mathrm{~F} \%$ 2Fwww.clarence.nsw.gov.au\%2Fpage.asp\%3Ff\%3DRES-MSS-33-27-08\&usg=AOvVaw3giL0kzJcL1UxLIC4tNWcQ (accessed on 1 January 2021).

141. Turner, R.K.; Paavola, J.; Cooper, P.; Farber, S.; Jessamy, V.; Georgiou, S. Valuing nature: Lessons learned and future research directions. Ecol. Econ. 2003. [CrossRef]

142. Zeleny, M. Entering the age of accelerated change: In search of equilibrium. Hum. Syst. Manag. 2021, 40, 3-14. [CrossRef]

143. Fusco Girard, L.; Nocca, F. From linear to circular tourism. Aestimum 2017. [CrossRef]

144. Zeleny, M. Multiple Criteria Decision Making (MCDM): From Paradigm Lost to Paradigm Regained? J. Multi-Criteria Decis. Anal. 2011, 18, 77-89. [CrossRef]

145. Ross, J.A.; Ben Jaafar, S. Participatory needs assessment. Can. J. Program Eval. 2006, 21, 131-154.

146. Fusco Girard, L. Capitale culturale intangibile e sviluppo locale "circolare". In Festività Carnevalizie, Valori Culturali Immateriali e Città Storiche; Colletta, T., Ed.; Franco Angeli: Milano, Italy, 2018; pp. 33-45. 